Portland State University

PDXScholar

\title{
A Social Systems Approach to Sustainable Waste Management: Leverage Points for Plastic Reduction in Colombo, Sri Lanka
}

Katie Conlon

Portland State University, conlon@pdx.edu

Follow this and additional works at: https://pdxscholar.library.pdx.edu/usp_fac

Part of the Urban Studies and Planning Commons

Let us know how access to this document benefits you.

\section{Citation Details}

Conlon, Katie, "A Social Systems Approach to Sustainable Waste Management: Leverage Points for Plastic Reduction in Colombo, Sri Lanka" (2021). Urban Studies and Planning Faculty Publications and Presentations. 305.

https://pdxscholar.library.pdx.edu/usp_fac/305

This Post-Print is brought to you for free and open access. It has been accepted for inclusion in Urban Studies and Planning Faculty Publications and Presentations by an authorized administrator of PDXScholar. Please contact us if we can make this document more accessible: pdxscholar@pdx.edu. 


\section{International Journal of}

Sustainable Development \& World Ecology

A social systems approach to sustainable waste management: leverage points for plastic reduction in Colombo, Sri Lanka

\begin{tabular}{|r|l|}
\hline Journal: & International Journal of Sustainable Development \& World Ecology \\
\hline Manuscript ID & TSDW-2020-0598 \\
\hline Manuscript Type: & Research Article \\
\hline Keywords: & $\begin{array}{l}\text { plastic pollution, plastic waste, sustainability, waste management, Sri } \\
\text { Lanka, social systems theory, SDG11 Sustainable Cities and } \\
\text { Communities < UN Sustainable Development Goals }\end{array}$ \\
\hline
\end{tabular}

\section{SCHOLARONE Manuscripts}




\title{
A social systems approach to sustainable waste management: leverage points for plastic reduction in Colombo, Sri Lanka
}

\begin{abstract}
Global plastic production continues to increase at an exponential pace, and global waste projections show waste generation rising by 70\% by 2050. Plastic waste connects to all social processes, especially within the context of urbanization and development; urban planning and land management; GHG emissions; labor; social equity; public health; rural-to-urban migration; increasing population; increasing consumption; climate change; etc. The focus of this research is an analysis of plastic waste management practices in Sri Lanka applying systems thinking, with a goal to better understand the social and ecological impacts of plastic waste in Sri Lanka. This research fills a gap in understanding the complex social dynamics that factor into plastic management, beyond the engineering of waste systems. The researcher works from the assumptions that waste is a social issue, that requires social responses that move beyond engineering and linear waste management; that designing a better or more efficient linear solid waste management system for the current realities of waste generation will only result in a continued, unsustainable waste system; and that plastics are truly a global challenge, relevant
\end{abstract}


for global south contexts, and these challenges require localappropriate solutions. The findings illuminate the network of local waste stakeholders, and highlight paths forward in waste reduction through patterns of behavior, structure, and mental modes that can lead towards a sustainable future for colombo.

Keywords: plastic pollution; plastic waste; waste management; sustainability; systems thinking; Sri Lanka

\section{Introduction}

Sorting out a more sustainable solution for the rising amounts of plastic waste and plastic pollution is one of the great challenges of our times. Global plastic production continues to increase at an exponential pace (Geyer et al., 2017), and global waste projections show waste generation rising by $70 \%$ by 2050 (Kaza et al., 2018). Waste generation and subsequent management are not stand-alone issues; waste issues connect to all social processes, especially within the context of urbanization and development (Hoornweg and Bhada-Tata, 2012). Most global south countries lack the means for managing plastics once thrown away (Hoornweg and Bhada-Tata, 2012), and the majority of plastics are thrown away after one use (Parker, 2017). Plastic such as PET bottles, food packaging, and shopping bags, cannot biodegrade, they leach harmful chemicals (Groh et al., 2019), 
and are dangerous for human and ecosystem vitality (Thompson et al. 2009).

World Bank analysts suggest that municipal solid waste management is the most important service that a city can provide, in both low and high-income countries (Hoornweg \& Bhada-Tata, 2012). Increasing urbanization is mirrored by increasing waste generation, as global waste is projected to rise 70\% by 2050 (Kaza et al., 2018). Currently 55\% of the world's population lives within an urban area, and this number is projected to rise to $68 \%$ by 2050 , with up to $90 \%$ of this growth being in Asia (UN DES, 2018). Waste management is still a challenge for most municipalities (Kaza et al., 2018; Wilson, 2015a), yet the cost of inaction to society on waste is estimated at 5-10 times the cost of management, and these losses include damages to health, productivity, increased flood risks, and damages to businesses, especially those within the tourism economy (Wilson et al., 2015a, b).

These considerations in mind, the focus of this research is an analysis of plastic waste management practices in Sri Lanka and the network of stakeholders engaged with these processes. The aim is to uncover leverage points for plastic waste reduction, and alternative strategies to the standard, linear, 
'take-make-waste,' waste generation to disposal model. The researcher uses a grounded theory based methodology - employing systems thinking, first-person interviews, and site visits with a goal to understand the complex social dynamics that factor into plastic management. The researcher works from three premises in this research: 1.) That waste is a social issue which requires social responses that move beyond engineering and linear waste management (Zero Waste Academy, 2017). 2.) That designing a better or more efficient linear solid waste management system for the current realities of waste generation will only result in a continued, unsustainable waste system (ibid; Connett, 2013; Zero Waste Cities, 2019; Zero Waste Europe, 2019). And, 3.) That plastics are truly a global challenge, relevant for global south contexts, and these challenges require local-appropriate solutions (GAIA, 2019, 2012). The researcher is curious to know about alternative, nonlinear pathways for waste management in the face of global waste challenges; and especially if local stakeholders are acknowledging these current waste realities - such as increasing use and disposal of plastic and lack of sustainable management options - and trying to find new ways to address the challenges of these waste streams. Although this case study is focused on the case of Colombo, this research incorporates a macro lens from the global plastic pollution/plastic waste narratives as 
these issues factor in and intersect (in the case of imported wastes) with the Colombo case (Azoulay et al., 2019; Connett, 2013; GAIA, 2019, 2018, 2012; Hamilton et al., 2019; Greenpeace, 2019; UNEP, 2018).

Ultimately, less plastic waste benefits human and environmental health through reductions in: environmental toxicity (Azoulay et al., 2019; European Commission, 2011); natural resource demands and carbon emissions (Azoulay et al., 2019; Hamilton et al., 2019); climate impacts (Azoulay et al., 2019); habitat impacts (Barnes et al., 2009; UNEP, 2014)); marine impacts (Gregory, 2009; IUCN, 2020; Rochman, 2015; UNEP, 2014); and human health impacts (European Commission, 2011; Halden, 2010; Knobauch, 2009; Maffini et al., 2006; Prata et al., 2020). Taking this perspective requires a departure from linear waste management models and a broadening of the field of 'why waste matters,' to a rationale of care and responsibility for social and ecological well-being, and ultimately the planet.

\section{Background on plastics}

Scientists call this the age of the Anthropocene (Crutzen, 2006; Steffen et al., 2007), whereby mankind, due to the "variety and longevity of human-induced change, including land surface transformation and changing the composition of the 
atmosphere" (Lewis \& Maslin, 2015: 171) has the greatest influence on the planet. Other scientists take the situation a step further and say that collectively we are beyond the Anthropocene and are within the era of the Plasticene, where plastic is humanity's most prominent legacy and what will remain for future generations to discover hundreds of years from now (Eriksen, 2015; Reed, 2015). The severity of plastics impact is critical, "The only way to permanently eliminate plastic waste is by destructive thermal treatment, such as combustion or pyrolysis. Thus, near-permanent contamination of the natural environment with plastic waste is a growing concern" (Geyer et al. 2017 ).

Wherever scientists turn, the impacts of plastic are made evident. Significant amounts of plastic waste ends up in waterways (Lebreton et al., 2017; Schmidt et al., 2017) and in the marine environment (Hermabessiere et al., 2017; Jambeck et al., 2015; Kershaw, 2015). ${ }^{1}$ Microplastics have now been found in once-pristine environments, such as the Arctic (Katz, 2019); in rain (Gregory et al., 2019); atmospheric deposits (Gasperi et al., 2018); in remote mountain lakes (Allen et al., 2019); at the bottom of the Mariana Trench (Gibbens, 2019); in tap water

\footnotetext{
${ }^{1}$ Marine debris pollution costs the Asian region $\$ 1.26 \mathrm{bn}$ per year in 2008 (McIlgorm et al., 2011), and the amount of plastic waste entering the oceans annually has been increasing, with current estimates at 8million tons a year (IUCN, 2020).
} 
(Tyree \& Morrison, 2017a); as well as in bottled water (Tyree \& Morrison, 2017b); in seafood (Smith et al., 2018); and even in fruits and vegetables (Conti et al., 2020; Li et al., 2020) as plastic particles bioaccumulate and assimilate within food systems and ecosystems. Moreover, many assume that plastic is an inert material, yet, as it degrades it releases chemicals, ethylene and the greenhouse gas methane (Royer et al., 2018), as well as leeches harmful additives, endocrine disruptors and carcinogenic substances (Azoulay et al., 2019; European Commission, 2011). Socially, waste is seen predominantly as a problem of the poor - linked class and sometimes ethnicity - and is displaced to marginalized communities (Bullard et al., 2008; Pellow, 2004). Due to the widespread impact of plastic waste, calls have been made for classifying plastics as a hazardous material (Rochman et al., 2013). In 2018, the Basel Convention which regulates the flow of hazardous waste worldwide, initiated a first step and amended the convention specifically for plastics, to put more regulations on global plastic waste trade flows in order to keep plastics out of the environment (Basel Convention, 2019).

One thing that all growing urban areas have in common is an excess of plastic waste. Every year, globally, plastic producers make over $400 \mathrm{~m}$ tons of plastic, and collectively $300 \mathrm{~m}$ tons of plastic is disposed of each year (Geyer et al., 2017; 
Laville \& Taylor, 2017). The amount of annual production of plastic is so large, it is almost incomprehensible. For instance, every hour nearly 55 million bottles are discarded globally, enough to create a pile larger than the Cristo statue in Brazil; in the past 10 years, 4 Trillion bottles have been thrown away; when manifested visually this amount dwarfs Manhattan (Ghosh, 2019). This works to the benefit of producers, for as long as they can mask the impacts of this production, they are given social license to continue to produce and perpetuate the petrochemical markets (McKay, 2019). Specifically, as the world shifts away from fossil fuels, petroleum companies are now shifting to cover their losses and are producing more and not less petrochemicals - in some cases over 40\% of production is going towards petrochemicals - which are the feedstocks for plastic (McKay, 2019; Tullo, 2019). According to current projections of the increase of plastics, by 2050 plastic production could account for $20 \%$ of global oil production (Giacovelli, 2018) and plastic waste could increase four times what we currently dispose of globally (Geyer et al., 2017). Most of this plastic burden falls on Asia (Brooks et al., 2018; Jambeck et al., 2015).

"Solid waste is the most visible and pernicious by-product of a resource-intensive, consumer-based economic lifestyle" (Hornweg \&Bhanda-Tata, 2012: 3). In a survey of waste management 
in the global south literature, every case sites environmental contamination as a result of lack of management, including air contamination, ground and surface water contamination, and disease vectors (Ferronato \& Torretta, 2019). Despite much publicity around the idea of recycling and recovery of plastics, to date this practice has not proved successful for the recovery and reuse of this material. Annually, 40\% of plastics are sent to landfills; 32\% is leaked directly into the environment; $14 \%$ incinerated and/or are used for energy recovery; and 14\% are collected for recycling, but of this only $2 \%$ is truly recycled (through a one-for-one recycling), 8\% downcycled and 4\% lost in the production process (World Economic Forum et al., 2016) (Geyer, 2017). Moreover, increasing waste generation compounds with existing urban growth challenges (Diaz, 2011) and impacts: air, water, and land pollution; GHG emissions; poverty and slums; and livelihood and equity. Waste challenges appear in global south contexts where: waste management systems are insufficient (Aleluia \& Ferrão, 2016; Diaz, 2011; Ferronato \& Torretta, 2019; Guerrero et al., 2013; Gourmelon, 2015; Hoornweg \& Bhada-Tata, 2012; Vidal, 2014); plastic packaging replaces organic (traditional) materials (Clapp \& Swanston, 2009); waste from the global north is shipped to the global south to dump or reprocess (Clapp, 2002; Kojima, 2009; Tue et al, 2013); toxic materials and 
environmental regulations are not in place and/or ignored for the sake of economic gain (Tian et al, 2011; Wang, 2017); civic society has limited input into the methods of handling waste materials and/or is not aware of the full impacts of waste (Knobaugh, 2009; Maffini et al., 2006); and historic legacies of environmental and social degradation (Medina, 2010, 2008). This research also contributes to broader dialogues on waste management in the global south, and joins the conversation with narratives on growth, consumption patterns, and unsustainable resource use (Klein, 2014; Hawken, 2017; Moore 2011; NorbergHodge, 2014). Ultimately, plastic waste generation imbalances and inequalities will continue to increase with growing consumption patterns and urbanization, if linear extractionproduction-use-disposal-repeat models persist.

\section{Systems Theory}

Systems theory says an unsustainable system is, "a system undermining its own means of support" (Meadows, 1999). In order to shift from an unsustainable to a sustainable system, the first step is to understand the systems processes that drive the systems. Systems are networks that consist of elements, interconnections, and overlapping functions/purpose (Meadows, 2008). Systems theory views a problem or challenge as part of a process or system, and not as an isolated event, and is a 
holistic and integrative way to look at problem-solving that is not reductionist (Meadows, 1999). Systems thinking helps to overcome the micro-macro divide and acknowledges how seemingly disparate parts and actors fit within the whole (Scharmer, 2013). Instead of focusing on the individual or individual events, "a system improves by strengthening the relationships among its parts" (Stroh, 2015; 120). Systems thinking draws network maps and feedback loops between what once seemed like disparate parts, and shows how it is all connected (Stroh, 2015). Analyzing actors and relationships that make up a systems network allows the researcher to understand linkages; gaps; blockages; collective intelligence and resources within the network; problem-solving pathways; and potential and leverage points for change (Freeman, 2004; Senge, 2006, 2014; Wiek et al., 2011).

Systems function as "the external manifestations of cultural thinking patterns and of profound human needs, emotions, strengths, and weaknesses" (Meadows, 2008: 167). The systems theory worldview includes traits such as focus on creating opportunities; people and knowledge based; long-term focus; dynamic and intuitive; and collective growth (Banathy 1996). If the system is broken and not functioning to bring about well-being, inquiring into the network of social patterns and interactions reveals blockages, deconstructs habitual 
patterns, and uncovers leverage points so that the system can transform in a positive way (Argyris \& Schon, 1978; Bausch, 2001; Capra \& Luisi, 2014; Checkland and Poulter, 2010; Meadows, 1997, 1999, 2008; Ricigliano, 2012, 2017; Scharmer, 2009, 2013; Scharmer\& Senge, 2009; Senge, 2006, 2013, 2014; Senge et al., 2005; Stroh, 2015).

Systems thinking values the vertical and horizontal integration of knowledge, and acknowledges that solutions can come from various places within the system (Meadows, 2008; Wiek et al., 2011). Applying systems thinking guides the researcher to understand waste systems patterns; provides the ability to reflect on positive and negative feedback loops; acknowledges interconnections and overlapping responsibilities and interests; and this framing avoids the habitual patterns of siloed problemsolving that recreates imbalances (ibid.). This research uses systems thinking to map the social network of waste stakeholders in Colombo, as well as consider the deeper levels of social change for shifting plastic waste practices. In doing so, the research works with systems thinking to connects the dots between interactions; listens to strategies for change; and inquires deeply within the network of stakeholders to create a dynamic picture of the current situation, and provide a point of departure for future waste decision-making (Checkland \& Poulter, 2010; Scharmer, 2015). 
Scharmer (2013) reflects on how trajectories in complex problem-solving scenarios often recreate problems they are trying to solve: "We collectively create results that nobody wants because decision-makers are increasingly disconnected from the people [and the environment] affected by their decisions" (46). This concept of 'trajectories' is important for understanding waste solutions, as for instance certain built mechanisms lock municipalities into long-term waste trajectories (i.e. building a new incineration plant that necessitates waste). Unsustainable waste processes are those that are not regenerative or supportive of circular life processes, and "interfere with nature's inherent ability to sustain life" (Capra \& Luisi, 2014: 353). Understanding ways to minimize and redirect unsustainable waste flows is fundamental for establishing a trajectory of waste minimization, with minimal social and ecological footprints in global north and global south countries alike. Systems thinking fosters the "change agents" and "transitions managers" for complex sustainability problems, and integrates, "use-inspired knowledge to transformational action in participatory, deliberative and adaptive settings" (Stroh, 2015: 203-04).

Highly complex problems require a framework for problemsolving different from the type of thinking that created the blockages in the first place (a shift from the general 
assumptions of waste management to materials awareness and waste reduction, for instance). Systems theory marks a paradigm shift from modes of mechanistic thinking and mechanistic worldviews, to ecological, holistic, and integrative thinking (Capra \& Luisi, 2014). Systems approach applies to various constructs: limits to growth (Goldsmith, 1972; Meadows et al., 1972); socioecological sustainability (Atkisson, 2012; Senge, 2013; Senge et al., 2013; Stroh, 2015); ecological and spiritual divide (Scharmer 2009, 2013); peace processes and complex social problems (Ricigliano, 2012); and climate change and the state of the world (Capra \& Luisi, 2014). The researcher has yet to see systems theory applied to waste issues, thus making this research an exciting new departure for the theory.

The Iceberg Model is a reference for the depth of systems thinking (Meadows, 2017; Senge, 2006). In the iceberg, the single event (tip of the iceberg), links to deeper patterns of behavior, structure, and mental models (the iceberg hiding below the surface). This model emphasizes both the capacity for change and learning that a system can undergo to reach this change. Systems questions for the Colombo waste context include: How might it be possible for actors within the system to work together in new ways and to share information and resources for plastic waste awareness and reduction? How can new solutions emerge when more stakeholders are involved? What are plastic 


\section{Context: Colombo, Sri Lanka}

Located in the Western Province of Sri Lanka, Colombo, the capital and the island nation's most populous city, is a pertinent site for researching plastic waste in the global south. The Western Province generates approximately $60 \%$ of the nation's waste - Sri Lanka has a population of approximately 21 million inhabitants (UN, 2012), and around a fourth of this population live in the greater Colombo area - and is the focal point of collection and distribution of goods as well as the recovery of materials for recycling and export. Urbanization and increasing consumption patterns in Colombo result in accumulating waste outputs (APO, 2007), coupled with waste management challenges (Fernando 2017; JAICA, 2016) that, when left unaddressed, link to an aggregation of problems including: the spread of disease; water contamination; respiratory illness; habitat destruction; species harm; aesthetic blight; social 
injustices; and 'zones of sacrifice' for polluting infrastructure.

Like many economically developing countries, sri Lanka is challenged with balancing pressures of development and sustaining the social and environmental richness at the heart of the Sri Lankan identity. Within this development discourse, waste currently grabs the attention of Sri Lankans due to rising awareness of waste impacts (Abhayagunawardena, 2017;

Bulathsinghala, 2017; Berenger \& Fazlulhaq, 2009; Dias, 2017; Kariyawasam, 2017; Nafeel, 2017; Weeraratne, 2017a, b). Waste in open landfills creates numerous social and ecological dilemmas, including the proclivity of waste piles to provide homes for mosquitos which creates corridors for diseases such as dengue (Ayomoh et al., 2008). Unstable trash heaps can cause flooding or landslides, as seen in the April 2017 Meethotamulla collapse that killed dozens and buried over 100 homes. Open waste pits also cause health impacts to wildlife, as many species including elephants scavenge these piles and regularly eat plastics (Rodrigo, 2017). Waste dumping and waste accumulation in the ocean disrupts marine life and creates hazards for fishing livelihoods and coastal health, on which Sri Lankans depend (Ministry of Fisheries and Aquatic Resources, 2017; World Bank, 2017); and studies now show the presence of microplastics in Sri 


\section{Methods}

The researcher hypothesizes that social structures and political and cultural dynamics play a formative role in the dominant practices to manage plastic waste. In general, waste management is conventionally framed from a linear, engineering perspective, to solve the waste problem with a technical solution (for instance, to design a more efficient machine) (Caruso et al., 1993; Hokkanen \& Salminen, 1997; Yadav et al., 2017). Delving into plastic waste issues from a socially based perspective contributes insights for understanding interactions, relationships, power, ethics, and social practices that

\footnotetext{
2 The irony is that designing a better linear solid waste management system for the current realities of waste generation results in a system that selfperpetuates by generating more and more waste.
} 
construct the management of plastic in Sri Lanka. Moreover, this approach does not presuppose the dominant narrative of management.

The research methodology includes: background document analysis on waste in the global south and Colombo; an extended stay in Colombo for field observations, site visits, and 49 indepth, key consultant interviews; stakeholder social network mapping; and thematic analysis from the interviews. The data collected from the interviews was used to construct a social network map, which provides a visual tool to understand the role social interactions play in upstream and downstream plastic management.

This research is decidedly a pragmatic approach to understand plastic waste practices, for the goal of improving waste minimization in the real world context. Using a case study method of Colombo is an in-depth method for collecting data in qualitative research and examining contemporary phenomena in the real world (Yin, 2014). Case studies allow the researcher to "examine social action in its most complete form," in all its complexity (Feagin et al., 1991: 9). This method shows a commitment to understanding social processes and patterns in order to promote social betterment (ibid). This method is appropriate for this research because "qualitative work enhances communication with the society and the world" (Gergen et al., 
2015: 1) and case studies are useful for understanding complex scenarios; doing exploratory research; descriptive research; analyzing the implementation and effects of policy on the ground; and analyzing processes of social change and social dynamics (Outhwaite \& Turner, 2007). The case of Sri Lankan materials flows could be called a 'crucial case' because of the current urgency and unresolved nature of the plastics problem (Given, 2008).

The 'how' and 'why' approach to case studies also lends itself to a critical, pragmatic lens. Taking a critical approach to social situations means deconstructing social norms to bring out alternative voices and alternative descriptions of the world (Hochstetler \& Laituri, 2014). In this process of describing the case, the researcher "makes us look again, in a fresh way, at that which we assume about the world because it has become overly familiar...in this way, new spaces are opened for thinking about the past and the present and, therefore, how we construct the world" (Fierke, 2001: 122). Describing the case, describing the actors involved, allows systems patterns to emerge that were previously hidden or obscured (Hochstetler \& Laituri, 2014). The field research in Colombo was on-and-off over a 2.5 year period. During the first four month period in Colombo, the researcher had dozens of informal \& semi-formal interviews with stakeholders such as waste industry directors; upcyclers; 
academics in the waste/environmental field; local nonprofits; local civic groups; etc. . These interviews were also used to 'snowball sample' for further people to include in the study. The researcher also used this time to collect reports. Collecting data in the field was important because there is no central repository or database for information on Colombo's waste situation (which means that even if reports are made, the historical memory can be very short).

The core of this research focused on in-depth key consultant interviews, that were conducted in the second 6 month stay in Colombo. Key ideas the researcher was looking for in each interview included: 1.) Stakeholder awareness of plastic waste management and challenges and interaction with other stakeholders; 2.) Strategies and solutions for the aforementioned; 3.) Blocks, gaps, and challenges; and, 4.) Leverage points for change, alternative materials use, and points of interconnection between stakeholders (see interview questions in Appendix). Stakeholder interviews included the following actor groups: national and local government officials, environmental lawyers, Sri Lankan and international NGOs, business owners, academics, recycling companies, plastic production companies, waste management directors, social enterprise, and concerned citizens groups. A diverse range of stakeholder interviews allows for voices from various points 
within the system to emerge, which clarifies why problems persist and highlights opportunities for collaboration, as well as highlights opportunities for shifting the waste system towards more socially and ecologically sound practices.

The interviews provided the bulk of the data, along with field visits, and relevant document review (academic articles, newspapers, government policy, and NGO reports). The interview notes were analyzed into two core themes of 'solutions' and 'blocks,' and from these subthemes were compiled, which reflects the diversity of voices within the waste stakeholder network. In total, the researcher completed 49 formal interviews, all of which were over one hour, some had a duration of over two hours; and some key consultants also partook in repeat interview discussions (as they were part of semi-formal interviews in the first phase and helped hone the interview questions). One interviewee afterwards decided they did not want their information used in the research, so officially the data from 48 interviews is used in this report.

Unforeseen issues in the research process included several disruptions. The researcher contracted severe dengue (ironically one of the impacts of plastic pollution) at the end of April 2018. From October 2018 through the first week in January 2019, Sri Lanka had a governmental crisis, where both Wickremesinghe and Rajapaksa were acting as prime minister, and effectively the 
government was not functioning (this meant no official government interviews, and most other offices were closed). And then at the end of April 2019, Sri Lanka was hit with a coordinated bombing, that destabilized the situation in colombo for several months. Other obstacles in the research process included the difficulty of contacting stakeholders and key consultants for interviews, often it took multiple phone calls, emails, even showing up at the office. In some cases it took over one month to coordinate a time to meet. This uncertain time duration highlighted the need to be in Sri Lanka, otherwise, one would not be able to complete the research. Also, the researcher discovered that email is often an ineffective mode of communication in Sri Lanka, especially with the government. An online survey, for instance, would have been the wrong method for gathering data. The researcher also would have liked to make sound recordings of all the interviews (to make it easier in the note-taking and transcription process); however, in the initial visit to Sri Lanka she observed an uneasiness by people to be interviewed. In order to have more fluid interview discussions, the researcher opted to do without the voice recording and take copious notes.

\section{Results}


2

Table 1: Interview Themes: Solutions proposed by stakeholders, and main blocks identified by the 48 key stakeholders interviewed.

\section{Solutions \& Strategies Blockages, Gaps}

1. Segregation of materials (segregation is primarily wet and dry in 1 . Systems blocks (i.e. lack of communication, interaction, Colombo)

2. Banning single-use (policy to enact change in plastic practices) Dethers)

2. Data \& historical memory (i.e. lack of current waste categorization by gov., last official study was +10 yrs ago and gov. continues to cite $6 \%$ plastic, although KOICA (2017) shows plastic almost triple)

3. Moving waste 'away' (landfilling; incineration; export recycling) 3. Materials awareness and capability gaps (human dimension)

4. Creative collaborations for waste (multi-stakeholder, across 4. Local capacity (structural, lack of recycling capabilities on domains such as Navy, MAS and BEIRA)

5. Boost existing efforts (from across domains such as existing recycling; existing collection; existing education efforts)

6. Spreading awareness (various forms of education) island, rely on export)

5. Policy and Governance (lack of access, lack of transparency, time lags, non-responsiveness)

7. Alternative materials and creative reuse (i.e. areca nut and banana leaf packaging; upcycling)

6. Transparency and Accountability (unclear pathways of responsibility)

7. Responsibility \& Burden of Knowledge (i.e. who is supposed to take action, citizens, government, business, or all?)

8. Neighborhood monitoring and education champions 8. Attitude Blocks (caste, NIMBY, poverty) (decentralized waste action)

9. Debunk the myth of "plastic as hygienic" to reveal health harms (i.e. endocrine impacts)
9. Agency and Access (i.e. who has access to waste streams, as well as who has access for making policy)

10. Urbanization, gentrification and busying lives in Colombo (waste concerns overlooked) 
Table 2: Further elaboration of themes generated by stakeholder interviews. Examples of quotations from the key consultant interviews as they relate to each of the main themes in Table 1; stakeholder code is in parenthesis.

\begin{tabular}{|c|c|}
\hline Theme & Example Quotation from Key Stakeholder Interviews \\
\hline Attitude & $\begin{array}{l}\text {-"Waste is seen as a poor man's business" (Ac) } \\
\text {-"People like to use easiest method so of course there are problems with compliance" (B) } \\
\text {-"Rural areas are easier to have conversations about waste; suburban new rich are harder to have } \\
\text { conversations" (INGO) } \\
\text {-"People will change if it fits within their business model, and do not have to let go of staff. Need to be } \\
\text { practical with solutions so can survive. However good intended, must be sustainable" (i.e. must sustain } \\
\text { business) (B) }\end{array}$ \\
\hline Awareness & $\begin{array}{l}\text { - "In villages [women] use plastic \& yoghurt cups as a Firestarter..."polythene baked rice"...especially } \\
\text { practiced during rainy season when its harder to get wood" (NGOV) } \\
\text {-"Right now the extent of EPR is just 'putting up bins'.. wanted to put } 200 \text { bins in schools" (B) } \\
\text { - "Need to teach kids, shop owners, give responsibility back to producer; encourage fines" (i.e. Give police } \\
\text { the authority to fine) (LGOV) } \\
\text { - "99\% people are aware of the [waste] issue" (SNGO) } \\
\text {-(Awareness challenge): "Different communities, different ethnicities, different messaging" (LGOV) }\end{array}$ \\
\hline Blockages/challenges & $\begin{array}{l}\text { - "Moment industrial waste leaves industry becomes MSW in Sri Lanka!" (B) } \\
\text {-'Delaying the inevitable if making [recycled plastic] brushes" (B) } \\
\text { - "Didn't stay long enough to make it work, [they] forget and move on ......Politics prevented a really } \\
\text { good deal from taking place" (INGO) } \\
\text {-"Local authority say garbage the Property of Municipal Council so people [recyclers] not supported to do } \\
\text { anything" (R) }\end{array}$ \\
\hline Historical Patterns/Context & $\begin{array}{l}\text { - "Start of open economy in Sri Lanka in } 1977 . . . \text { increased consumerism but people didn't realize the } \\
\text { consequences" (Ac) } \\
\text { - "Pyrolysis plant opened in } 2008 \text { in BOI Horana. Only ran for six years" (B) } \\
\text { - "Colombo established in the British era, the city can't expand..totally urbanized, rushed, no plan here" } \\
\text { (PGOV) } \\
\text {-"the aquifer is just 3-4 meters deep" (NGOV) }\end{array}$ \\
\hline Gap & $\begin{array}{l}\text { - "It's scary talking to ministers, they don't want to hear from kids" (Civ) } \\
\text { - "New solid waste policy doesn't consider liquid or gas waste, covers priority area waste" (i.e. hospital, } \\
\text { industry) (NGOV) } \\
\text {-"Local authorities don't have a mechanism to use sorted garbage, but still ask to sort" (SNGO) } \\
\text {-"Have not done categorization yet of waste collected" (LGOV) }\end{array}$ \\
\hline Leverage & $\begin{array}{l}\text {-[On Diapers]: "have enough water to do a washing service here, but now the culture will need to be } \\
\text { shifted back" (NGOV) } \\
\text { - "If a local authority can produce project plan, with payback potential, they can get loan with low interest } \\
\text { with a 2-3 year grace period...they don't have to wait for provincial government to allocate money" } \\
\text { (NGOV) } \\
\text { - "Awareness programs for temples, government officials, schools" (NGOV) } \\
\text { - "social media is very successful to target kids and housewives, whose free time is on social media" (Civ) }\end{array}$ \\
\hline
\end{tabular}


-[On alternative material] "biggest problem there is no market... not easily marketable" (i.e. coconut, areca, banana) (SNGO)

-[on LDPE]: "very usable, no ban, and competition for recycling” [On HDPE] "only bag ban, other materials not banned" [On PP] "pellets can be used for any kind of injection mold" [On PET]: "sort and sell to companies under the radar" $(\mathrm{R})$

- "Free trade zone prohibits access to excess materials and waste but could be a huge potential there" (Ac) -[on challenges for collection]: "PVC contamination and lack of systems for PET bottle collections" (R)

Responsibility

-[On business] "realize have a social license" (B)

- "Everyone talks about wanting to do the right thing, but it doesn't happen" (P)

-[responsibility gap]; "Every local authority is mandated to make a composition analysis one time a year" (LGOV)

- "No policy consistency, when government changes, policy changes" (PGOV)

Solutions

- "Composting not successful because people put [their compost] in plastic bags"

- "Conscious consumerism.. try to make a habit for kids"

- "Need 40-50 collection centers island wide.... scale up, baling, weighing, pay for PET" (R)

- "The 10 R's: Reject, refuse, reduce, reuse, repair, replace, recycle, rethink, remember, repeat." (SNGO)

- "Community waste/resource banks at council level" (SNGO)

\section{Strategy/TOC}

-[On greenwashing]: "CSR mismatch such as plastic [business] and planting [trees]" (Ac)

- "Create community awareness by targeting different sectors of population...sschool kids, women's groups, community orgs, credit groups, youth groups, hotel associations, low income communities" (SNGO)

-[Strategy to commit]: "Sign agreement with local homes" (SNGO)

-[strategy fail]: "plastic policy is the perfect example of "wrong decision-making"" (NGOV)

Systems

- "Households completely confused about recycling. Even educated people don't know! Consumers are confused, so many kinds of plastic, what to do?" (INGO)

- "paper bottle man" [takes] glass bottles, newspapers, cardboard, but not plastic" (Ac)

- "Rich politicians take waste contracts" (Ac)

- "Very complicated at bottom levels" (i.e. informal collectors) (Ac)

- "Recyclers are not keen on changing what they're are doing, they don't see the opportunity to change their existing business model; [they] also don't have the capital for machines" (B)

Waste statistics

-"49 municipal councils in western province with 7 zones (each zone manager coordinate with local authority and plan and communicate). haven't done a composition [analysis] in over 10 years." (PGOV) -[there are] "over 100 collectors/'recyclers' but only one formal recycler BEIRA, [which makes] polyester for Adidas and Nike... [operate] at below $50 \%$ but get over $205 \mathrm{mt}$ a month [PET] .....approx. $1400 \mathrm{mt}$ in the Sri Lankan economy - 400 collected, 200 exported - [which leaves] about $800 \mathrm{mt}$ left behind and hard to capture" (R)

-" $22 \%$ of CMC budget is management and disposal, every 4years is a $5 \%$ increase" (LGOV) -"White Bottle/clear glass: $1 \mathrm{~kg}=4.5 \mathrm{r}$; colored glass: $1 \mathrm{~kg}=1 \mathrm{r}$; PET: $1 \mathrm{~kg}=25 \mathrm{r}$; Paper: $1 \mathrm{~kg}=6 \mathrm{r}$; cardboard: $1 \mathrm{~kg}=10 \mathrm{r}$; coconut $1 \mathrm{~kg}=10 \mathrm{r}$ " (LGOV)

Table 3: Coding of stakeholders. These labels were used to code information from the interviews, to provide supporting evidence of the themes and discussion.

\begin{tabular}{|l|l|}
\hline \multicolumn{1}{|c|}{$\begin{array}{l}\text { Stakeholder } \\
\text { Classification }\end{array}$} & Code \\
\hline Business & B \\
\hline Plastic Manufacturer & P \\
\hline Recycler/Recovery/Upcycler & R \\
\hline Sri Lankan NGO & SNGO \\
\hline International NGO & INGO \\
\hline National Gov (ministry) & NGOV \\
\hline Local Gov & LGOV \\
\hline Provincial Gov & PGOV \\
\hline Academics & AC \\
\hline
\end{tabular}




\begin{tabular}{|l|l|}
\hline Association (business) & Assoc \\
\hline Civic Organization & Civ \\
\hline Field Visits/time in field & FV \\
\hline
\end{tabular}

The interviews, site visits and document analysis show that the dominant waste discourse in colombo is one of a linear trajectory to the landfill; but the emerging discourse is one of minimization and resource recovery. The interview themes and subthemes were highlighted through thematic analysis of the interview discourse, and key ideas relating to plastic waste awareness reduction were highlighted [Table 1 \& 2]. A social network map was created using the data from the interviews [Figure 1] to show interactions amongst waste stakeholders, in order to visualize the system fully, and consider how the network both helps and harms plastic reduction efforts. Gaps in interaction in the network highlight lack of access, and blocks to collaboration. Connections also signify ideas sharing, such as ideas on zero waste practices, or alternatives to plastics. The network map is a live mapping application that can be accessed online (via the link in the Figure 1 caption), designed to be a tool for stakeholders to use to work on blockages as well as seek new modes of collaboration.

Table 1 highlights the main points of discussion that came out of the interviews on plastic waste challenges, as well as strategies and solutions to address these challenges. These 
themes all derive from the key stakeholder interview process. ${ }^{3}$ The researcher began coding while transcribing the notes, and started broadly in order to be able to capture all of the concepts discussed by the key consultants and then at the end narrowed into key themes. At the end of the transcription process, certain themes were beginning to stand out. The broader list of thematic areas included these subheadings: single-use; lunch sheets; segregation; clean-ups; enforcement; leverage; 'government getting in the way'; hazardous waste; E-waste; health aspects; attitude; symbolic gestures; 'ease of change'; greenwashing; corruption; the system; theory of change/strategy; gaps; context; awareness; policy; partners; foreign influence; and responsibility. By the time coding was finished, the researcher surmised that issues could be best addressed by focusing on the main themes, as addressed in the solutions and blockages sections, as well as highlighting key actions for reducing plastic waste. The themes were organized in this way to be 'actionable' by stakeholders (pragmatic applied research). Themes evolved as the researcher reread the interviews and transcribed all the notes (working with interview data). Many aspects of the interview discussions fall between categories. For instance, the quote, "waste is seen as poor man's business

\footnotetext{
${ }^{3}$ Each theme is described in greater detail in Conlon (2020).
} 
but still rich people control at the top" (Ac) can fit in the category of system, as well as attitude, and awareness (of the system). In another example, this quote similarly addresses a number of overlapping issues of attitude, (points of) leverage, responsibility, and government blocks: "99\% of people are aware of the [waste] issue...even rural people are willing to make changes...but the system does not allow...[and citizens] blame the government" (SNGO). Certain categories stood out as clear cut, such as single-use bans, so whenever a stakeholder discussed single-use that sentence was highlighted, such as, "We encourage minimization of single-use plastics across the company" (B). Similarly, on other specific topics like e-waste, the themes were able to be pulled out directly, as relayed in the quote, "Sri Lanka signed and stamped all treaties but still has no ewaste processing" (R). Or as one interviewee describes several blocks within one statement, "Government policy is not strong enough to manage the waste we hand over to them. Media is not supportive for change making, [and the] school education system should be changed for such positive changes" (SNGO). This statement touches upon the blockages themes of government blocks; awareness (blocks); and responsibility of various stakeholders. In one statement, one government agency specifically said that they, "Do not work with NGOs because our agendas don't match" (NGOV). These types of decisive statements 
show both system and collaboration blockages. Additionally, time spent in the field helped the researcher decipher multiple meanings within what was said, for instance the remark, "waste is [the] environment" (SNGO), references the impact that waste has on the environment, but also that waste in the Sri Lankan context is managed through the Ministry of the Environment. In order to make the stakeholder map, the researcher triangulated several data sources for the lines of connection: what was said by stakeholders, what the researcher learned in field visits, as well as connections revealed in articles, newspaper, and NGO reports [Figure 1]. In the map, the lines of connection represent a connection (not degrees of connection). This map is interactive online, and one can zoom in and out to see how all the different stakeholders are connected to each other.4 The degree to which all of the stakeholders are connected shows that CEA has the most connections (27); followed by Good Market (23); other local authorities (12); Ecospindles (12); CMC (10); EFL (10); and informal waste pickers (9). This information can be referenced when considering decision-making and solutions trajectories. In the online system, one can also highlight specific characteristics of the stakeholder network to see how

\footnotetext{
4 The map was constructed to only reveal the publicly available information, and does not identify any of the stakeholders by what was said in the interviews.
} 
certain aspects unite or divide the network. The nodes are colored accordingly to highlight (in different selection windows) stakeholders working towards: education and awareness; clean-ups; youth advocacy and inclusion; alternative materials; and whether stakeholders receive foreign support for their programs. For instance, highlighting the 'education and awareness' characteristic and one can see that most stakeholders have an aspect of this within their programming. If so much energy is spent on education and awareness, and the system operates at the current status quo, this leads to the question of what does all of this 'awareness' actually accomplish and what is it aimed for? Highlighting the tab for 'foreign support,' one can see the stakeholders that depend on foreign money for their waste agenda. Foreign dependency for waste programs can influence what kind of actors and what kinds of waste efforts get funded.

By highlighting individual stakeholders within the network, one can also see gaps in communication and interactions that can provide critical information on network blockages - as well as opportunities for change. To give a few different examples, first look at CEA, the most 'networked' stakeholder on the map, with 27 connections across the network (Figure 11). CEA is the National policy making body for waste, and therefore has many high-level, official connections. However, as evidenced in the 
map, CEA is not connected to informal waste pickers, and only has one connection with civic organizations. This signifies a gap between the policy making level and the on-the-ground reality. Essentially those on the ground dealing with waste issues on a daily basis, and also civic groups with emotional strong-ties to the waste issue, are not included within the formal waste management system. Similarly, examining the connections of CMC (Colombo Municipal Council), they are not connected with any of the recyclers. When considering alternative ways of recovering and processing material, if the official waste management entity of Colombo is not connected with those offering materials solutions, this does not bode well for materials recovery (Figure 12). In another example, highlighting Coke, one can also see how the network operates and that Coke has several high level connections (at the Ministry, with the Chamber of Commerce, etc.), which gives them agency and access and allows them to lobby for suitable policy for their operations (for instance, taking a stance against single-use plastic bottle bans). Examining the network from the perspective of those who are advocating for plastic reduction, Good Market stands out as a leader as a hub (with 23 connections) for spreading awareness about zero waste and plastic free packaging options. Although Good Market is highly networked with local enterprise, they lack 
the higher-level, lobbying connections when compared to Coke. Similarly, local NGOs and civic organizations that work on waste awareness and reduction are networked predominantly horizontally (amongst each other) rather than vertically.

In the elements function on Kumu, one can also select 'promotes alternatives' [to plastic] and visually see which stakeholders are actively promoting alternatives, as well as the connectivity within the network between those that promote and for instance, those who make policy and have agency to enact macro changes to the system (Figure 2). The visual shows those who promote in blue, and illustrates a significant divide within the system. Zooming closer, one can see that the alternatives come predominantly from the local social enterprise, and those that do not promote alternatives are some of the key government stakeholders. With this knowledge about the network, one can identify that alternatives that are emerging within the network of stakeholders do not have the same opportunities to access and influence policy; and also that policymakers are not aware of everything beneficial that is happening on the ground for waste reduction. 


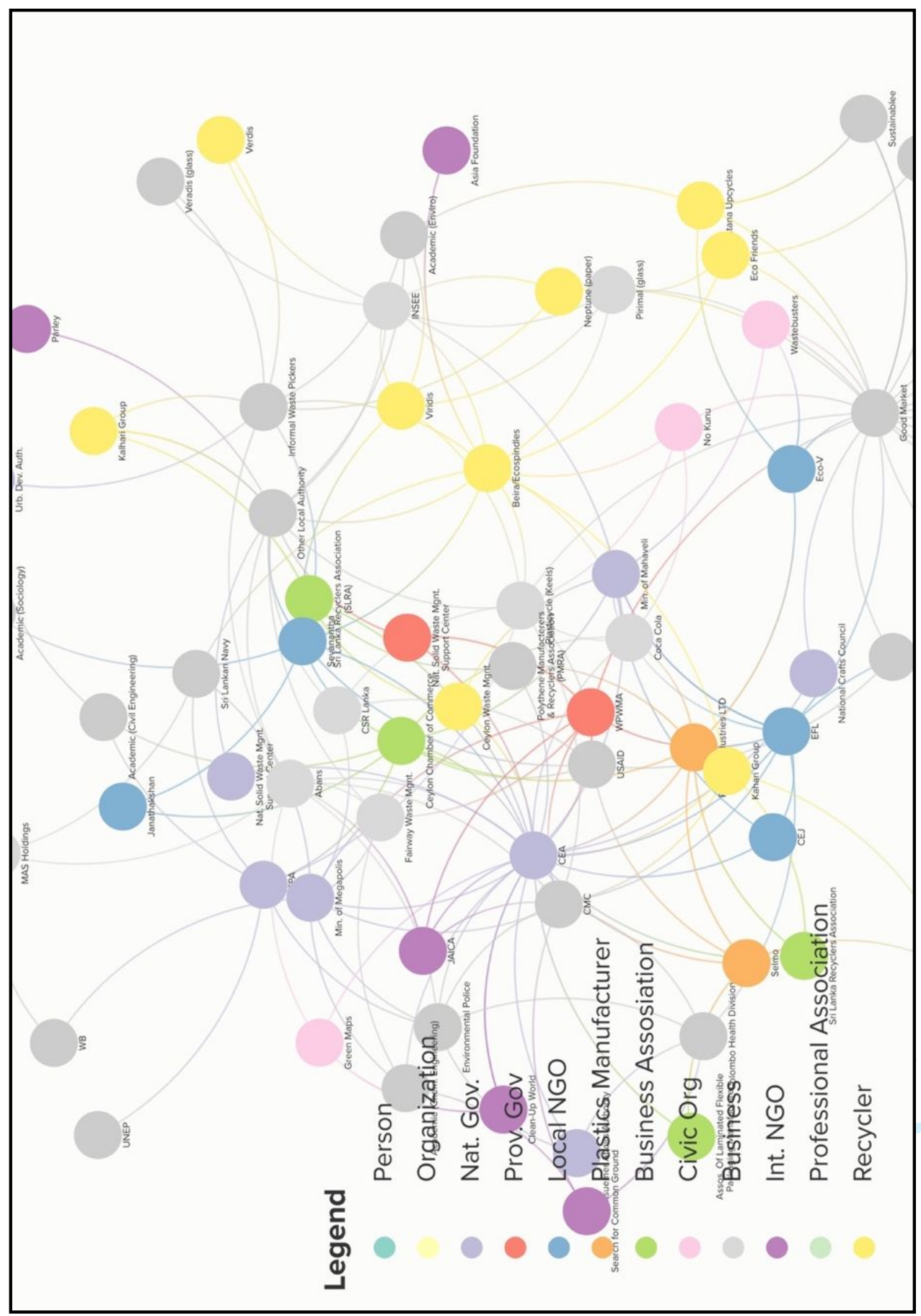

Figurel: Social Network Mapping of Key Consultants on waste in Colombo. This map illustrates the complexity of the waste network in Colombo, and is a tool to visualize the network of actors. This map shows network pathways for waste action between actors in the Sri Lanka system. Nodes show types of actors involved within the system, as well as their domain (i.e. Local NGOs, Recycling Companies, National Government, etc). Some connections illustrate current waste challenges as well as block change; while 
others contribute towards shifting waste practices. Note: all stakeholder network map images are screenshots from the online portal. The formatting is not optimal for these images because it is fluid for the online viewing and interacting. View here: https://kumu.io/kconlon7/colombo-waste-key-stakeholders

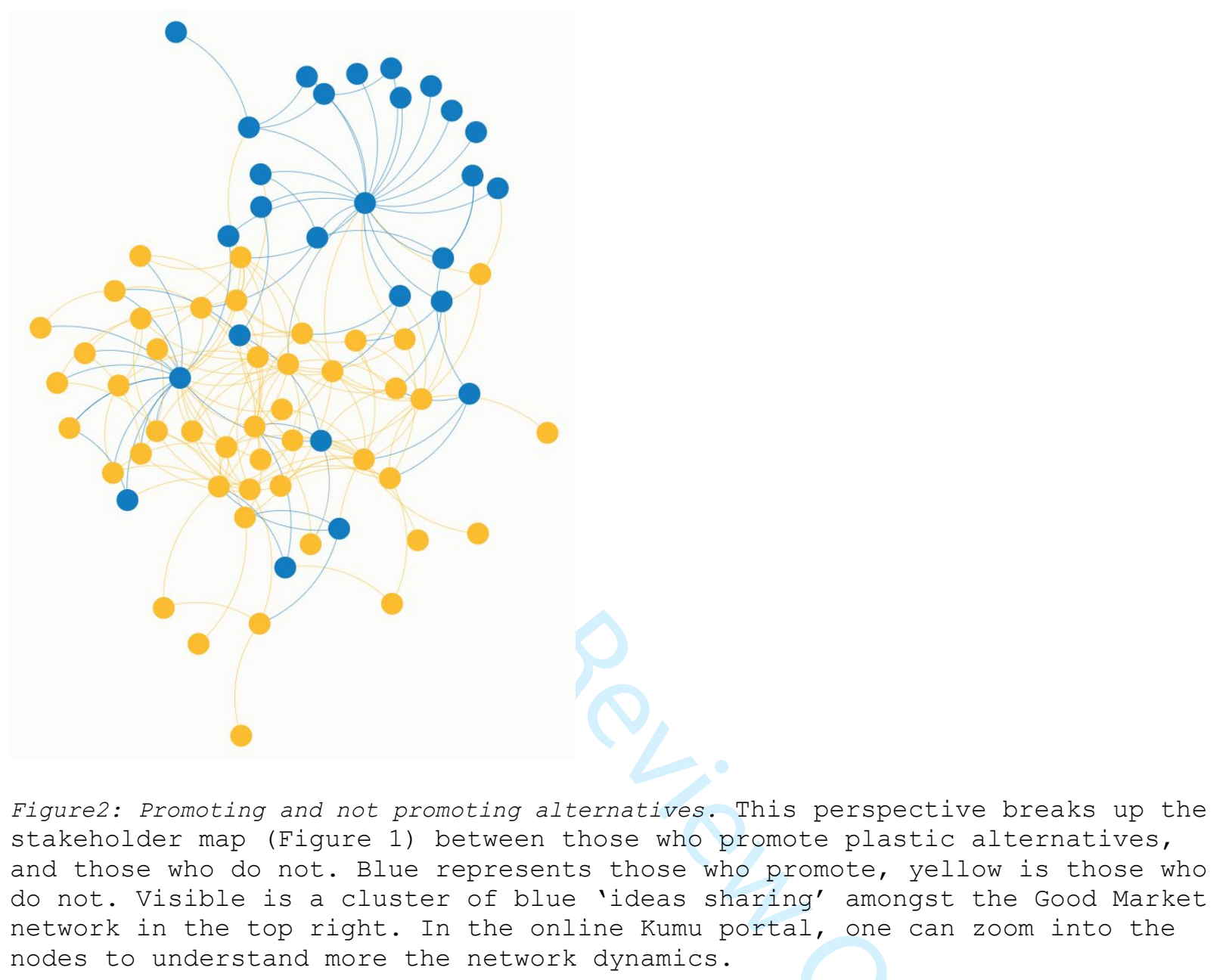




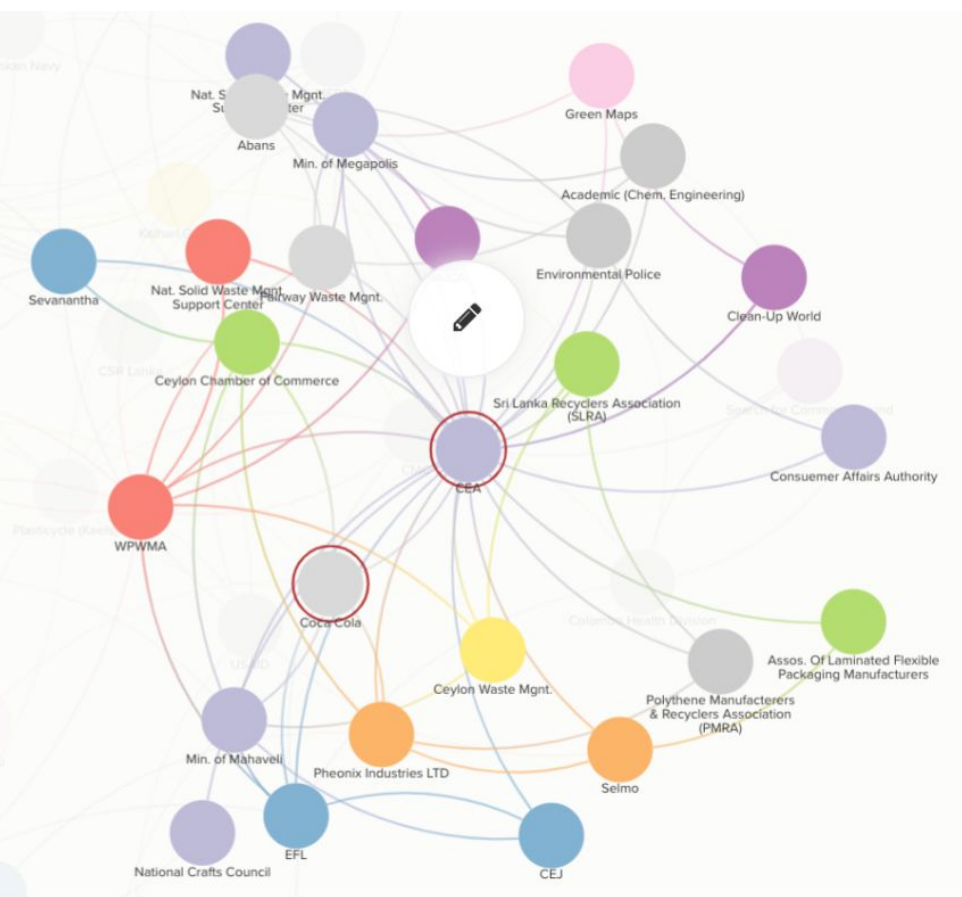

Figure 3: The 27 connections of the Central Environmental Authority (CEA). A visual example of their network capacity as well as connection blockages, for instance, to civic organizations.

\section{Analysis}

The system of linear waste management in Colombo ignores solutions existing within the network of stakeholders such as further segregation of materials (Civ, INGO, SNGO, R, NGov, Ac); banning single-use (SNGO, Civ, Ac); creative collaborations for waste (B, Civ, Ac, R, SNGO); boosting existing efforts from outside the municipal channels (B, R, INGO, Civ, SNGO, Ac); focusing on alternative materials (to plastics) (B, Civ, NGov); neighborhood monitoring and local champions (Civ, LGov); and taking a more critical look at the health impacts of plastics (LGov, SNGO, Civ). Furthermore, the linear approach allows for the systems blocks (all); the gaps in data and historical memory 
(INGO, Ac); infrastructure and training capabilities gaps (PGov, NGov, LGov, R, B, Assoc); knowledge gaps (LGov, Ac, B, Civ); transparency and accountability (Civ, SNGO, INGO); responsibility lapses (Civ, SNGO); policy gaps (LNGO, Civ, INGO, LGov); attitude blocks (all); and overlooking increasing pressures of urbanization (INGO, SNGO, Ac). The system map [Figure 1] shows a diversity of actors engage on waste issues, yet those who are working towards solutions for waste reduction are predominantly not those who are making the policy and managing the existing waste systems. For instance, the local government body responsible for waste management, Colombo Municipal Council (CMC), is not connected to any civic organizations, recyclers, or informal materials recoverers. The Central Environmental Authority (CEA), responsible for making national level waste policy, is not connected to civic organizations or informal recoverers either, which results in practical level understanding about the waste system to be overlooked.

The system of linear waste management in Colombo ignores solutions existing within the network of stakeholders such as further segregation of materials (Civ, INGO, LNGO, R; banning single-use; creative collaborations for waste; boosting existing efforts from outside the municipal channels; focusing on alternative materials (to plastics); neighborhood monitoring and local champions; and taking a more critical look at the health impacts of plastics. Furthermore, the linear approach allows for the systems blocks; the gaps in data and historical memory; 
capabilities gaps; local capacity gaps; transparency and accountability; responsibility lapses; policy gaps; attitude blocks; issues of access; and overlooking increasing pressures of urbanization to continue. Essentially, within the network are solutions that could help minimize the social and ecological impacts of waste, as well as work towards waste reduction; however, the management system is not currently designed to collaborate with all stakeholders.

When considering pathways for change, systems thinking can differentiate between solutions that only solve for one problem, and solutions that consider the interdependence of complex issues (Berry, 2005). Looking only at one aspect of the system, such as increasing waste infrastructure, can lead to a false notion of problem-solving (O'Brien \& Sygna, 2013). Incomplete solutions include when destructive patterns are not fundamentally resolved and impacts are displaced to other parts of the network. Incomplete solutions are rife in existing waste management models, for instance: filling up one waste dump and then building another, creating more pollution locations (i.e. Meethotamulla to Mutharajawela landfill) (SNGO, INGO, Civ); incinerating materials which destroy resources, and perpetuating the cycle of virgin material extraction (two incineration projects are in construction) (SNGO); moving waste from one location to another through cleanups (Civ, SNGO); limiting 
segregation of materials to only two categories (wet and dry) which results in limited recovery and most material ending up in landfill (R, Ac, B, Civ, SNGO); etc. Systems waste management, however, follows the premises of systems theory which emphasizes social responsibility and ecological responsibility, and that an injustice or imbalance anywhere, is a threat to systems balance as a whole (Bausch, 2001).

The current Colombo waste management emphasis on downstream management affects how and where one can physically 'see' waste; however, it does not address the output of waste, and ultimate social and ecological impacts. For a true shift in discourse, waste management needs to shift from the idea of better-managed wastes to ultimately less waste (through alternative materials and alternative practices). The government emphasis on collection, and not minimization (Civ); segregation and not recovery ( $\mathrm{R})$; and recycling pledges without the capacity (INGO, R), which shows a disconnect between the practices of waste management and the realities on the ground. The emphasis for management has entered into the civic psyche, too, as wellmeaning citizens participate in beach cleanups, and at the end of the cleanup, throw the waste collected into the landfill or burn it on site (Civ). Households also have an increased awareness in segregation post-Meethotamulla collapse, however, 
there is limited awareness about what happens to waste once it leaves their doorstep (SNGO, Civ, Ac). Essentially, moving waste (or matter-out-of-place resources) from one environmental context to the next might accomplish peace of mind for the municipality or for citizens; but ultimately waste in either of these contexts is disruptive to the environment and adjacent neighbors.

Meadows (1997) describes leverage points as places to intervene in a system. These are points where, when the system is blocked, working from these points can nudge the system to shift in a different direction. In the case of waste in Colombo, leverage points represent bright spots in the narrative, and highlight opportunities for stakeholders to delve into areas such as: alternative materials to use other than plastics (B, Civ, SNGO, NGOV, Ac); waste reduction strategies (SNGO, Civ, Ac); collaborations for waste reduction (B, R, INGO, SNGO, Civ, Ac). Such leverage points can be emphasized in designing and strategizing new waste systems, such as piloting community-level zero waste plans. The leverage points identified, moreover, highlight the diversity of waste actors and the implicit knowledge, experience, agency, and scope that goes beyond mere management of waste.

Leverage points in the Sri Lankan context are areas where the system can shift from primarily 'downstream' waste 
management to an 'upstream' cultural shift approach. Systems thinkers often use the analogy of an overflowing bathtub. When the bathtub is overflowing what do you do, grab a mop and start cleaning up, or turn off the tap? It seems obvious to turn off the tap, however, in the case of waste management in colombo and similarly in other linear, waste management systems - what really happens is that stakeholders allow waste generation to continue, and grab the mop: more beach cleanups; focus on collection; build bigger landfills; build incinerators; add more technical infrastructure for managing waste; etc. This is the current status quo waste management emphasis in Colombo. Figure 4 shows this process of linear management; and Figure 5 highlights the deeper layers of patterns of behavior, structure and mental models that can integrate more dimensions and stakeholders to address the plastic waste challenges of Colombo. Table 3 shows that shifting from linear management to a systems management approach opens up the waste space for an increase of stakeholder involvement (optimizing the network) and increase in materials valuation, recovery, and plastic reduction. 


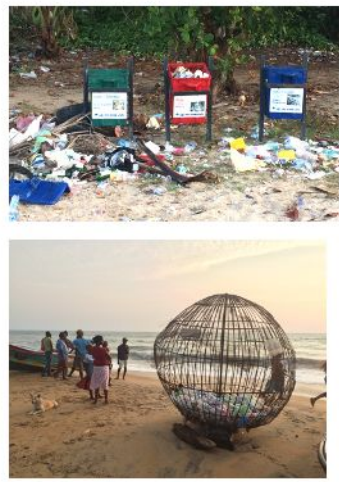

Generation of Waste ('event')

Linear System, predominant system

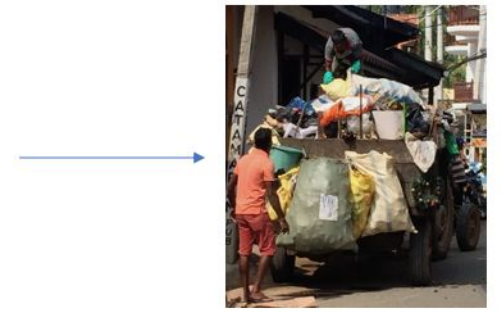

Management $=$ Collection (with possible segregation, But no clear pathways for Reducing or recovery)

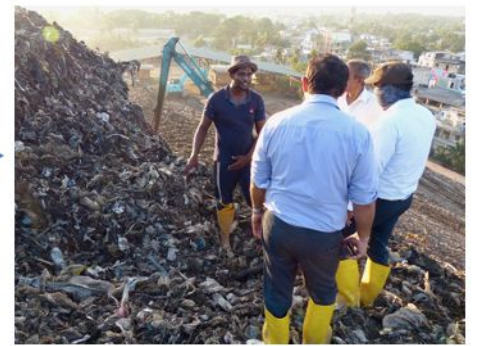

Disposal in open Landfill (minimal recycling, predominantly Through informal channels/economy)

Figure 4: Current linear waste-to-landfill trajectory. With current management frameworks, this system perpetuates in Colombo. The fraction of waste that is collected is taken to one of the open landfills such as Mutharajawela or Karadiyana.

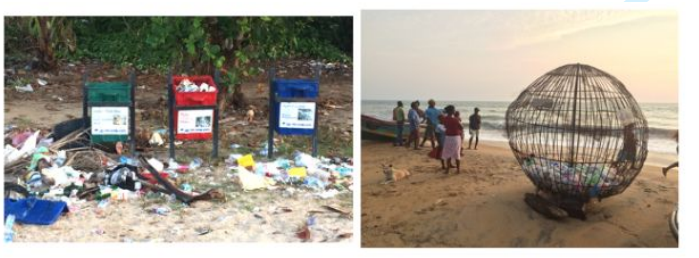

\section{Shift from linear waste management to new systems approach}

\section{PATTERN OF BEHAVIOR}

\section{STRUCTURE}

\section{MENTAL MODELS}

New strategy/policy filter, will result in new kinds of transactions, new politics of waste

Addressing how the parts are related \& connect

Addressing values, beliefs, culture related to 'waste' to see materials as resources; minimize waste; awareness of broader environmental \& social impacts etc.
Banning single-use or zero waste incorporated into policy, which alters the way waste is seen \& requires community cooperation and collaboration; supporting waste champions

Collaboration amongst a diverse set of stakeholders (i.e. circular pathways to use wastes as resources); support existing network of waste workers (wastepickers, recyclers)

Changed through supporting narratives that advocate for upstream awareness and action on waste; creating a plastic-free culture and/or a waste-as-resource culture

Figure5: From linear waste management to a deeper systems approach. The linear approach does not allow for inclusion of all of the actors within the network; nor is it adequately incorporating ideas for overall waste reduction such as zero waste. The current management approach does not allow for more socially and ecologically responsible management options to emerge. 
Table 3: Shifting from linear management to systems management. Systems thinking includes patterns, structure, and mental models that significantly increases the amount of waste stakeholders involved from the ground up, and allows for plastic reduction strategies to emerge. In parentheses shows the stakeholder that is primarily concerned with these waste practices.

\begin{tabular}{|l|l|}
\hline & \multicolumn{1}{|c|}{ Waste Practices and Associated Stakeholders } \\
\hline LINEAR SYSTEM & $\begin{array}{l}\text { Waste Haulers (B); Local, Provincial, National Gov. (NGov, PGov, LGov); } \\
\text { Waste to energy (B); landfill owners (B) }\end{array}$ \\
\hline PATTERN OF BEHAVIOR & $\begin{array}{l}\text { Single-use ban advocates (Civ, I/SNGOs); plastic bag ban advocates (Civ, } \\
\text { I/SNGOs); zero waste advocates (citizens, I/SNGOs, B); environmental } \\
\text { awareness advocates (citizens, SNGOs, R); cleanups (Civ); waste edu } \\
\text { programs (Civ, B, SNGO, R, Ac) }\end{array}$ \\
\hline STRUCTURE & $\begin{array}{l}\text { Upcycling \& Fix-it centers (Civ \&B); Reuse (Civ); Recyclers (R, INGO, } \\
\text { Civ); ZW businesses (B, R, Civ); EPR structures (Civ); alternatives to } \\
\text { plastics businesses and craftspeople (B, Civ, SNGO); Community } \\
\text { collection \& compost (decentralized waste) (Civ, B, R) }\end{array}$ \\
\hline MENTAL MODELS & $\begin{array}{l}\text { Professors teaching/researching about waste impacts, microplastics, } \\
\text { upcycling, zero waste strategy etc. (Ac, Civ, B, Lgov, SNGO); Zero Waste } \\
\text { champions (Civ, SNGOs); }\end{array}$ \\
\hline
\end{tabular}

A shift away from a linear waste model to a systems model would address patterns of behavior, structure, and mental models (Meadows, 2017; Senge, 2006) that could create an entirely new waste paradigm for Colombo. Considering the environmental and social blights of increasing waste streams, if the current linear system continues it will wreak increasing harm on the environment and vulnerable communities. Systems waste management shows a way forward that includes a multiplicity of solutions as well as a multiplicity of stakeholders within the existing 
system. In essence, Colombo does not need to reinvent the wheel for a more accountable waste management system, authorities just need to listen and incorporate those within the system. Shifts in policy such as single-use bans address patterns of behavior (proposed by SNGOs and Civ); creating new means for materials to flow, such as extended producer responsibility (EPR) (proposed by $B$ as well as NGOV) address structure; and aspects like new learning models at schools and universities, and public awareness campaigns, target a shift in mental models (proposed by NGOV, Civ, B, SNGO, INGO, R, Ac). Combining these efforts can create a plastic waste reduction trajectory.

Waste is political, social, ecological, economic and cultural; what is 'thrown away' essentially lies at a confluence of forces. There is not a silver bullet, single path for waste solutions, but a multiplicity of options as illustrated through the systems management analysis. Leverage points can be used to move beyond the highly politicized context of Sri Lankan waste politics, and towards solutions that emphasize reduction rather than distancing. Waste should be seen as a unifying topic beyond normal politics, as everyone suffers the effects of a nonfunctioning waste system. As waste management and waste streams become more complex - new forms of plastics, e-waste, new systems of recycling - the challenge is to integrate a plurality 
of voices into the decision-making processes so that environmental and social concerns are heeded.

\section{Implications for the Global Waste Dialogues}

The microcosm of Sri Lanka shows us that the dialogues on waste reduction are predominantly happening outside of politics: by local businesses, civic organizations, and NGOs. Thus, broadening the dialogue on waste is important for identifying alternatives to plastic and current waste practices. In the Sri Lankan case, international businesses and NGOs working on waste issues - and the money they bring - do not prioritize a lens of plastics and waste reduction, but emphasize sharing of technology within the framework of the linear waste status quo (i.e. through engineered landfills; partnering on incineration; financing collection programs). In the context of other developing nations battling their own waste crisis one can ask: What trajectory of waste management is being funded by foreign investment, linear waste perpetuation or waste reduction? The stakeholder network map for waste stakeholders in Colombo shows that plastic waste is an issue that extends beyond the normal, linear confines of waste management experts - to students, lawyers, professors, manufacturers, recyclers, local and international businesses, local and international organizations, etc. When deconstructing and addressing the 
plastic waste issue in other contexts, including the diverse local network of stakeholders will help to construct policy and implementation that is locally-appropriate, locally-feasible, and inclusive of environmental and social concerns. Islands especially do not always have the infrastructure capacity to recycle all materials (for instance, the Philippines with over 7000 islands, and their plight with TETRA ). In this case, what is an ecologically acceptable distance to ship waste and/or recycling, if at all? How does waste management intersect with the carbon footprint? Can Local stakeholders be encouraged to find out solutions for excess materials (such as the Bottle-Up project to reuse glass on Zanzibar Island, which has an excess of glass with no recycler (Bottle-Up, 2020). How can local artisans and manufacturers be supported to create alternatives to plastics to support local businesses as well as livelihoods (such as seaweed to replace plastics, grown in Indonesia (Augustin, 2020)? As waste is a cultural artifact of what is externalized locally, every community, town and city has the opportunity to examine what is 'wasted' and figure out what can be refused, minimized, redesigned and reused within the local context. For cities ready to take this step, the Global Alliance for Incineration Alternatives recently created a Zero Waste Masterplan and website that acts as both rough guide and 
inspiration for these local actions happening at a global scale (GAIA, 2020).

\section{Conclusion}

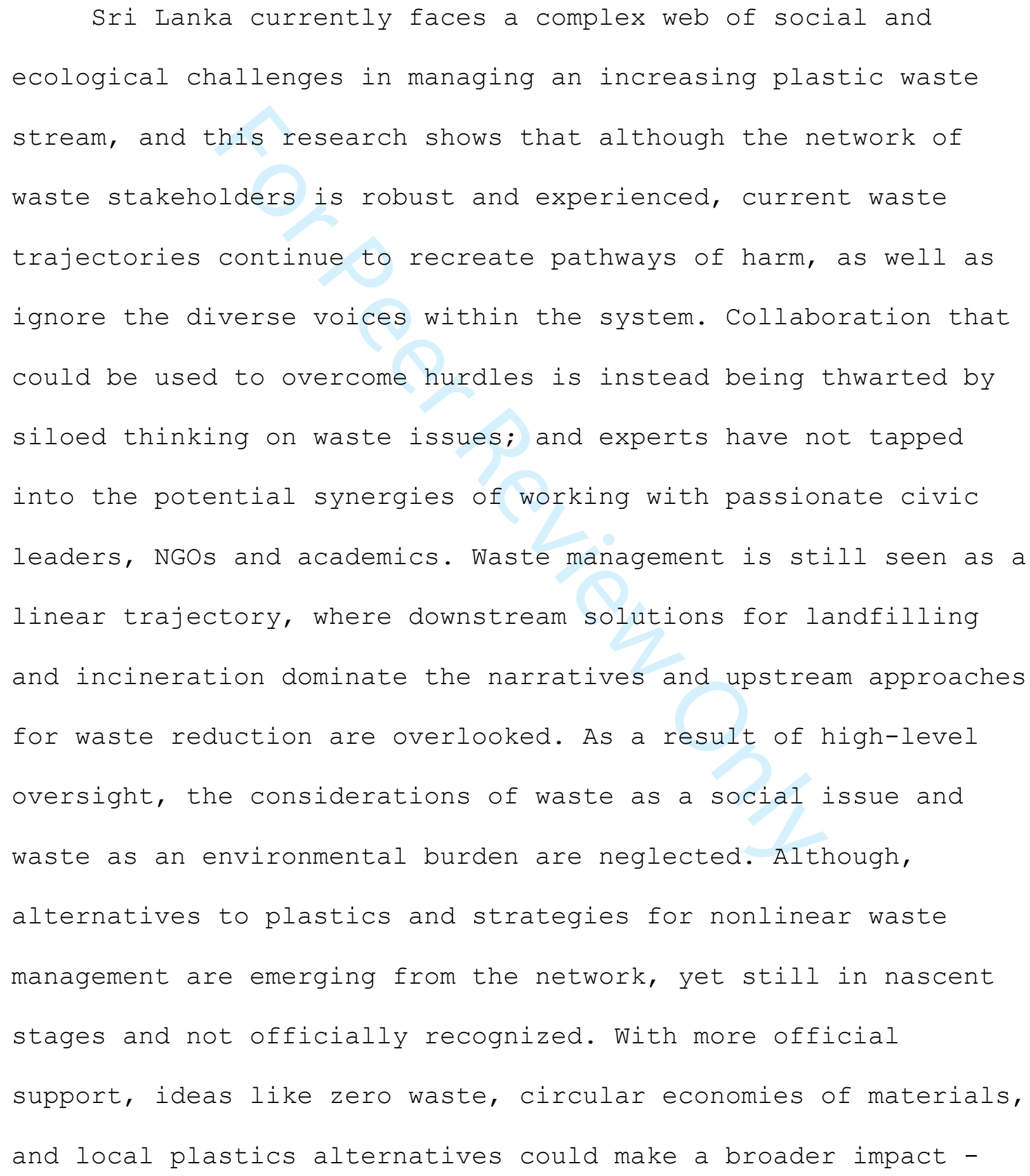


even serve as regional and global examples. If those within the Colombo waste network acknowledge the shortfalls of the current waste system, then these alternatives pose ready solutions for practices to work beyond the current waste management practices. Ultimately, this research concludes that not only does Colombo's linear model of waste management perpetuate the wasteful resource-to-landfill model (and soon to follow the resources-to-incineration model), and these trajectories limit the amount of collaboration between stakeholders within the local context. Sri Lanka has a diverse network of waste stakeholders, and if more attention is paid to the system's actors as a whole, deeper level systems change can emerge from the existing knowledge and expertise within the network. The analysis outlines contextually-appropriate ways for waste reduction change to occur through patterns of behavior, structure, and mental modes (Meadows, 2008). Shifting from linear waste management to a systems management plan will significantly increase the amount of waste stakeholders involved, address social and ecological concerns, and allow for new and existing plastic reduction strategies to emerge. Learning from the waste context in Sri Lanka, this research contributes to emerging dialogues on waste imbalances and injustices in the global south, as well as broader dialogues on 
consumption; critiques of the growth paradigm; and strategies for environmentally and socially sound waste practices.

\section{References}

Abhayagunawardena, V. (April 15, 2017). The Politics of Garbage in Sri Lanka \& the Need for Recycling Plants. The Colombo Telegraph. Retrieved from: https://www. colombotelegraph. com/index.php/the-politics-of-garbage-in-srilanka-the-need-for-recycling-plants/

Aleluia, J., and Ferrão, P. (2016). Characterization of urban waste management practices in developing Asian countries: A new analytical framework based on waste characteristics and urban dimension. Waste Management, 58, 418-429.

Allen, S., Allen, D., Phoenix, V. R., Le Roux, G., Jiménez, P. D., Simonneau, A., Binet, S., \& Galop, D. (2019). Atmospheric transport and deposition of microplastics in a remote mountain catchment. Nature Geoscience, 12(5), 339344 .

APO. (2007). Solid Waste Management: Issues and Challenges in Asia. Environmental Management Centre, Ed. Asian Productivity Organization: Tokyo.

Argyris, C. and Schon, D. A. (1978). Organizational Learning: A Theory of Action Perspective. Melano Park, CA: Addison-Wesley Publishing Co.

Atkisson, A. (2012). The sustainability transformation: How to accelerate positive change in challenging times. Routledge.

Augustin, J. (2020). In a race for a sustainable alternative to plastic, Indonesia bets on seaweed. Monagabay. Retrieved on Nov. 18, 2020, from: https://news.mongabay.com/2020/03/in-race-for-a-sustainable-alternative-toplastic-indonesia-bets-on-seaweed/

Ayomoh, M. K. O., Oke, S. A., Adedeji, W. O., \& Charles-Owaba, O. E. (2008) . An approach to tackling the environmental and health impacts of municipal solid waste disposal in developing countries. Journal of environmental management, 88(1), 108-114.

Azoulay, D., Villa, P., Arellano, Y., Gordon, M., Moon, D., and Miller, K. (2019). Plastic and Health: the hidden cost of a plastic planet. CIEL. 1-76.

Barnes, D. K., Galgani, F., Thompson, R. C., \& Barlaz, M. (2009) Accumulation and

fragmentation of plastic debris in global environments. Phil. Trans. of the Royal Soc. B: Bio. SCi. 364, 1985-1998.

Basel Convention. (2019). Plastic Waste Partnership. Basel Convention. Retrieved on October 18, 2019, from: 
http://www.basel.int/Implementation/Plasticwastes/PlasticWastePartnership/tab id/8096/Default.aspx

Bausch, K. C. (2001). The Emerging Consensus in Social Systems Theory. New York: Kluwer Academic/Plenum Publishers.

Berenger, L., and Fazlulhaq, N. (March 22, 2009). Garbage crisis growing by the day. Sunday Times. Retrieved from:

http://www.sundaytimes.1k/090322/News/sundaytimesnews_00200903221.html

Berry, W. (2008). Digging In. The Sun. Retrieved from:

http://thesunmagazine.org/issues/391/digging_in?page=2

Bottle-Up. (2020). The Story. Retrieved on Nov. 18, 2020, from:

https://wWw. bottle-up.org/about

Brooks, A. L., Wang, S., \& Jambeck, J. R. (2018). The Chinese import ban and its impact on global plastic waste trade. Science advances, 4(6), eaat0131.

Bulathsinghala, F. (April 26, 2017). Garbage - A look at Sri Lanka, South Asia and beyond. Financial Times. Retrieved from:

http://www. ft.lk/article/611329/Garbage-\%E2\%80\%93-A-look-at-Sri-Lanka--SouthAsia-and-beyond

Bullard, R. D., Mohai, P., Saha, R., \& Wright, B. (2008). Toxic wastes and race at twenty: why race still matters after all of these years. Envtl. L. 38,371 .

Capra, F. \& Luisi, P. L. (2014). The systems view of life: A unifying vision. Cambridge University Press.

Carillo, Philippe and Maxine (Producer \& Director). (2015). Inside the Garbage of the World: The Ugly Truth about Plastic Pollution. [documentary]. Oxnard, CA: PCMC Films.

Caruso, C., Colorni, A., \& Paruccini, M. (1993). The regional urban solid waste management system: A modelling approach. European journal of operational research, $70(1), 16-30$.

Checkland, P. and Poulter, J. (2010). Soft Systems Methodology. In Systems approaches to managing change: A practical guide. Springer: London. pp. 191242 .

Clapp, J. (2002). The distancing of waste: Overconsumption in a global economy. Confronting consumption, 155-176.

Clapp, J. and Swanston, L. (2009). Doing away with plastic shopping bags: international patterns of norm emergence and policy implementation. Environmental Politics, 18(3), 315-332.

Connett, P. (2013). The Zero Waste Solution: Untrashing the Planet One Community at a Time. White River Junction, VT: Chelsea Green Publishing.

Conlon, K. (2020). Waste Management in the Global South: An Inquiry on the Patterns of Plastic and Waste Materials Flows in Colombo, Sri Lanka [Ph.D. Dissertation]. PDX Scholar. https://www.youtube.com/watch?v=a7X-J1DhfjE (forthcoming) 
Conti, G. O., Ferrante, M., Banni, M., Favara, C., Nicolosi, I., Cristaldi, A., ... \& Zuccarello, P. (2020). Micro-and nano-plastics in edible fruit and vegetables. The first diet risks assessment for the general population. Environmental Research, 109677.

Crutzen, P. J. (2006). The "Anthropocene". In Earth system science in the Anthropocene. Springer Berlin Heidelberg, 13-18.

Dharmadasa, W. L. S. S., Andrady, N. L., Kumara, P. B. T. P., \& Gangabadage, C. S. (2019). Assessment of microplastics contamination in marine protected areas in Southern Sri Lanka. NARA. Retrieved on Feb. 17, 2020, from: http://www.erepository.nara.ac.lk/handle/1/1653

Diaz, L. F. (2011). Solid Waste Management in Developing Countries: Status, Perspectives and Capacity Building. Intergovernmental Preparatory Meeting for CSD-19. UN Headquarters. 1-35. Retrieved from:

https://sustainabledevelopment.un.org/content/documents/ldiaz.pdf

Eheliyagoda, D., and Prematilake, N. (2016). Assessment of Planned Municipal Solid Waste Management System in Sri Lanka. J. App. Sci. Environ. Manage., 20 (1), 58-61.

Emens, R. (2014). The Not-So-Endless Ocean: How the Cost of Convenience Is Closing In on Us. Seattle J. Envtl. L., 4, 131.

Environmental Foundation Ltd. (EFL). (2007). Climbing out of the Garbage Dump: managing Colombo's solid waste problem. EFL: Colombo.

Eriksen, M. (Dec. 15, 2015). World's Most Comprehensive Study Shows More Plastic in Our Ocean Than Scientists Thought. Ecowatch. Retrieved on October 24, 2019, from: https://www.ecowatch.com/worlds-most-comprehensive-studyshows-more-plastic-in-our-oceans-than--1882129942.html

European Commission (2011). Science for Environment Policy: Plastic Waste: Ecological and Human Health Impacts. European Commission. 1-41.

Feagin, J. R., Orum, A.M., and Sjoberg, G. (1991). A Case for the Case Study, Chapel Hill: The University of North Carolina Press.

Fernando, R. L. S. (2019). Solid waste management of local governments in the Western Province of Sri Lanka: An implementation analysis. Waste management, 84, 194-203.

Fernando, M. (May 4, 2017). Sri Lanka Struggles to tackle waste problem. AlJazeera. Retrieved from: http://www.aljazeera.com/video/news/2017/05/srilanka-struggles-tackle-waste-problem-170504080405461.html

Ferronato, N., \& Torretta, V. (2019). Waste mismanagement in developing countries: A review of global issues. International journal of environmental research and public health, 16(6), 1060.

Fierke, K. (2001). Critical Methodology and Constructivism. In Karin Fierke and K. E. Jorgensen [Eds]. Constructing International Relations: The Next Generation. Armonk, NY: M. E. Sharp, 115-35. 
Freeman, L. C. (2004). The Development of Social Network Analysis: A Study in the Sociology of Science. Vancouver, BC: Empirical Press.

GAIA. (2020). Zero Waste World. Retreived on Nov. 18, 2020, from: https://zerowasteworld.org/zwmp/

GAIA. (2019). Plastics Exposed: How Waste Assessments and Brand Audits are Helping Philippine Cities Fight Plastic Pollution. Quezon City, Philippines: GAIA. 1-60.

GAIA. (2018). Facts About "Waste-To-Energy" Incinerators. Global Alliance for Incinerator Alternatives (GAIA). Retrieved on November 10, 2019, from: www. no-burn.org

GAIA. (2012). On the Road to Zero Waste: Successes and lessons from around the world. Global Alliance for Incinerator Alternatives (GAIA). Retrieved on November 10, 2019, from: wWw.no-burn.org

Gasperi, L., Wright, S., Dris, R., Collard, F., Mandin, C., Guerrouache, M., Langlois, V., Kelly, F.J., \& Tassin, B. (2018). Microplastics in air: Are we breathing it in? Environmental Science \& Health, 1, 1-5.

Gergen, K. J., Josselson, R., \& Freeman, M. (2015). The promises of qualitative inquiry. American Psychologist, $70(1), 1-9$. doi:http://dx.doi.org.proxy.lib.pdx.edu/10.1037/a0038597

Geyer, R., Jambeck, J. R., \& Law, K. L. (2017). Production, use, and fate of all plastics ever made. Science Advances, 3(7), e1700782.

Giacovelli, C. (2018). Single-Use Plastics: A Roadmap for Sustainability. UNEP. 1-92.

Gibbens, S. (2019). Plastic proliferates at the bottom of the world's deepest ocean trench. National Geographic. Retreived on Sept. 17, 2020, from: https://www.nationalgeographic.com/news/2018/05/plastic-bag-mariana-trenchpollution-science-spd/

Given, L. M. (2008). The Sage Handbook of qualitative research methods, Los Angeles, CA: Sage Publications.

Goldsmith, E. (1972). A Blueprint for Survival, Boston: Houghton Mifflin.

Gourmelon, G. (2015). Global Plastic Production Rises, Recycling Lags. Worldwatch Institute. Retrieved from http://www.worldwatch.org/globalplastic-production-rises-recycling-lags-0

Greenpeace. (2019). Throwing away the future: How Companies Still Have it Wrong on Plastic Pollution "Solutions." Greenpeace. 1-34.

Gregory, M. R. (2009) Environmental implications of plastic debris in marine settings-

entanglement, ingestion, smothering, hangers-on, hitch-hiking and alien invasions. Phil.

Trans. of the Royal Soc. B: Bio. Sci. 364, 2013-2025.

Groh, K. J., Backhaus, T., Carney-Almroth, B., Geueke, B., Inostroza, P. A., Lennquist, A., ... \& Warhurst, A. M. (2019). Overview of known plastic 
packaging-associated chemicals and their hazards. Science of the Total Environment, 651, 3253-3268.

Gunaruwan, T. L., \& Gunasekara, W. N. (2016). Management of Municipal Solid Waste in Sri Lanka: A Comparative Appraisal of the Economics of Composting. NSBM Journal of Management, 2(1), 27-45. DOI:

http://doi.org/10.4038/nsbmjm.v2i1.19

Gunasekara, R. (Aug. 14, 2019). Colombo Port City has no sewage treatment \& disposal Plans. Ceylon Today. Retrieved on October 29, 2019, from:

https://ceylontoday.1k/news-more/6480

Halden, R. U. (2010). Plastics and Health Risks. Annu. Rev. Public Health, $31,179-94$.

Hamilton, L. A., Feit, S., Muffett, C., Kelso, M., Rubright, S. M., Bernhardt, C., Schaeffer, E., Moon, D., Morris, J., and Labbe-Bellas, R. (2019). Plastic \& Climate: The Hidden Cost of a Plastic Planet. CIEL. 1-98.

Hermabessiere, L., Dehaut, A., Paul-Pont, I., Lacroix, C., Jezequel, R., Soudant, P., \& Duflos, G. (2017). Occurrence and effects of plastic additives on marine environments and organisms: A review. Chemosphere, 182, 781-793.

Hokkanen, J., \& Salminen, P. (1997). Choosing a solid waste management system using multicriteria decision analysis. European journal of operational

research, $98(1), 19-36$.

Hoornweg, D. and Bhada-Tata, P. (2012). What a Waste: A Global Review of Solid Waste Management. World Bank. 1-116.

IUCN. (2020). Marine Plastics. Retrieved on Sept. 17, 2020, from:

https://www.iucn.org/resources/issues-briefs/marine-

plastics\#: : : text=cups\%20and\%20straws.-

,At $\div 20$ least $\% 208 \% 20 \mathrm{million} \div 20$ tons $\% 200 \mathrm{f} \div 20$ plastic $\% 20$ end $\% 20$ up $\% 20$ in, waters $\% 20$ to $\% 2$ 0deep $\div 2$ Dsea $\% 20$ sediments.

JAICA \& Kokusai Kogyo Co., Ltd. (2016). Data Collection Survey on Solid Waste management in Democratic Social Republic of Sri Lanka. JAICA. Retrieved on October 14, 2019, from: http://open jicareport.jica.go.jp/pdf/12250213.pdf

Jambeck, J.R., Geyer, R., Wilcox, C., Siegler, T.R., Perryman, M., Andrady, A., Narayan, R. and Law, K.L. (2015). Plastic waste inputs from land into the ocean. Science, 347(6223), pp.768-771.

Kariyawasam, Dr. P. (May 5, 2017). Dengue Epidemic: Back to Basics is Needed to Prevent the Spread. The Sunday Leader. Retrieved from:

http://www. thesundayleader.1k/2017/05/07/dengue-epidemic-back-to-basics-isneeded-to-prevent-the-spread/

Katz, C., (2019). Why does the Arctic have more plastic than most places on earth? National Geographic. Retreived on Sept. 17, 2020, from:

https://www.nationalgeographic.com/science/2019/10/remote-arctic-containsmore-plastic-than-most-places-on-earth/

Kaza, S., Yao, L., Bhada-Tata, P., \& Van Woerden, F. (2018). What a waste 2.0: a global snapshot of solid waste management to 2050. Washington, DC: World Bank Publications. 
Kershaw, P. J. (2015). Sources, fate and effects of microplastics in the marine environment: a global assessment. Rep. Stud. GESAMP, 90, 96.

Klein, N. (2014). This changes everything: capitalism vs. the climate. New York: Simon \& Schuster.

Knobauch, J. A. (2009). Plastic Not-So-Fantastic: How the Versatile Material Harms the Environment and Human Health. Scientific American. Retrieved from: https://www.scientificamerican.com/article/plastic-not-so-fantastic/

KOICA. (2017). Waste Characteristics Survey. Sri Lanka: KOICA.

Kojima, M., Yoshida, A., and Sasaki, S. (2009). Difficulties in applying extended producer responsibility policies in developing countries: Case studies in e-waste recycling in China and Thailand. J Mater Cycles Waste Manag, 11, 263-269.

Koongolla, J. B., Andrady, A. L., Kumara, P. T. P., \& Gangabadage, C. S. (2018). Evidence of microplastics pollution in coastal beaches and waters in southern Sri Lanka. Marine pollution bulletin, 137, 277-284.

Laville, S. , and Taylor, M. (June 28, 2017). A million bottles a minute: world's plastic binge 'as dangerous as climate change.' The Guardian. Retrieved from: https://www.theguardian.com/environment/2017/jun/28/amillion-a-minute-worlds-plastic-bottle-binge-as-dangerous-as-climate-change

Lebreton, L. C., Van der Zwet, J., Damsteeg, J. W., Slat, B., Andrady, A., \& Reisser, J. (2017). River plastic emissions to the world's oceans. Nature communications, 8, 15611.

Lewis, S. L., \& Maslin, M. A. (2015). Defining the Anthropocene. Nature, 519(7542), 171.

Li, L., Luo, Y., Li, R., Zhou, Q., Peijnenburg, W. J., Yin, N., ... \& Zhang, Y. (2020). Effective uptake of submicrometre plastics by crop plants via a crack-entry mode. Nature Sustainability, 1-9.

Liyanage B, Gurusinghe R, Herat S, Tateda M (2015) Case study: finding better solutions for municipal solid waste management in a semi local authority in Sri Lanka. Open J Civil Eng (5), 63-73.

MacBride, S. (2011). Recycling Reconsidered: The present failure and future promise of environmental action in the United States. Cambridge, MA: MIT Press.

Madusanka, K. H. P., Matsuto, T., Tojo, Y., \& Hwang, I. H. (2017). Questionnaire and onsite survey on municipal solid waste composting in Sri Lanka. Journal of Material Cycles and Waste Management, 19(2), 804-814.

Maffini, M. V., Rubin, B. S., Sonnenschein, C., and Soto, A. M. (2006). Endocrine disruptors and reproductive health: The case of bisphenol-A. Molecular and Cellular Endocrinology, 254-255, 179-186. 
McIlgorm, A., Campbell, H. F., \& Rule, M. J. (2011). The economic cost and control of marine debris damage in the Asia-Pacific region. Ocean \& Coastal Management, 54(9), 643-651.

McKay, D. (Oct. 10, 2019). Fossil fuel industry sees the future in hard-torecycle plastic. The Conversation. Retreived on sept. 16, 2020, from: https://theconversation.com/fossil-fuel-industry-sees-the-future-in-hard-torecycle-plastic-123631

Meadows, D. H. (2008). Thinking in systems: A primer. Vermont: Chelsea Green Publishing .

Meadows, D. H. (1999). Sustainable Systems [video]. Ross School of Business, University of Michigan. Retrieved from:

https: //www . youtube. com/watch?v=HuIoego-xVc

Meadows, D. H. (1997). Places to Intervene in a System. Whole Earth, Winter. Retrieved on Feb. 17, 2020, from:

https://www.bfi.org/sites/default/files/attachments/pages/PlacesInterveneSyst em-Meadows.pdf

Meadows, D. H., \& Club of Rome. (1972). The Limits to growth: A report for the club of Rome's project on the predicament of mankind. New York: Universe Books.

Medina, M. (2010). Scrap and Trade: Scavenging Myths. Development \& Society. Retrieved from: https://ourworld.unu.edu/en/scavenging-from-waste

Medina, M. (2008). The informal recycling sector in developing countries. Gridlines, 44, 1-4.

Ministry of Fisheries and Aquatic Resources Development. (2017). Fisheries of Sri Lanka. Retrieved from: http://www. fisheries.gov.lk/content.php?cnid=ststc

Moore, J. W. (2011). Transcending the metabolic rift: a theory of crises in the capitalist world-ecology, The Journal of Peasant Studies, 38:1, 1-46, DOI : $10.1080 / 03066150.2010 .538579$

Nafeel, N. (April 21, 2017). Changing trashing habits. Daily News. Retrieved from: http://dailynews.1k/2017/04/21/features/113744/changing-trashing-habits

Norberg-Hodge, H. (2014). Localization: Essential Steps to an Economics of Happiness. Local Futures, International Society for Ecology and Culture.

O'Brien, K., \& Sygna, L. (2013). Responding to climate change: the three spheres of transformation. Proceedings of Transformation in a changing climate, 19-21.

Outhwaite, W. \& Turner, S. P. (2007). Case study. In The SAGE handbook of social science methodology, SAGE, pp. 102-120. doi: 10.4135/9781848607958.n6

Parker, L. (July 19, 2017). A Whopping 91\% of Plastic Isn't Recycled. National Geographic. Retrieved from: https://news.nationalgeographic.com/2017/07/plastic-produced-recycling-wasteocean-trash-debris-environment/ 
Pellow, D. N. (2004). Garbage wars: The struggle for environmental justice in Chicago. Cambridge, MA: MIT Press.

Prata, J. C., da Costa, J. P., Lopes, I., Duarte, A. C., \& Rocha-Santos, T. (2019). Environmental exposure to microplastics: an overview on possible human health effects. Science of the Total Environment, 134455.

Rathnayaka, V. L., Amarathunga, A.A.D.,, Jayasiri, H.B., \& Liyanage, H. D. (2019). Microplastics Contamination in Selected Beaches of Sri Lanka. ResearchGate. Retrieved on February 8, 2020, from: https://www.researchgate.net/publication/338169768 Microplastics Contaminatio $\underline{n}$ in Selected Beaches of Sri Lanka

Reed, C. (2015). Dawn of the Plasticene Age. New Scientist, 225(3006), 28-32.

Ricigliano, R. (2017). Systems Practice. +Acumen Course. Received from: http://www.plusacumen.org/courses/systems-practice

Ricigliano, R. (2012). Making peace last: A toolbox for sustainable peacebuilding. New York: Routledge.

Rochman, C. M. (2015) The complex mixture, fate and toxicity of chemicals associated with plastic debris in the marine environment, in: Bergmann M., Gutow L., Klages M. (Eds) Marine anthropogenic litter, Springer, Cham.

Rochman, C.M., Browne, M.A., Halpern, B.S., Hentschel, B.T., Hoh, E., Karapanagioti, H.K., Rios-Mendoza, L.M., Takada, H., Teh, S. \& Thompson, R.C. (2013) Policy: Classify plastic waste as hazardous, Nature, 494(7436), 169.

Rodrigo, M. (March 5, 2017). Deadly garbage dumps pose elephant problems. The Sunday Times. Retrieved from: http://www.sundaytimes.1k/170305/news/deadlygarbage-dumps-pose-elephantine-problems-231517.html

Royer, S. J., Ferron, S., Wilson, S. T., \& Karl, D. M. (2018). Production of methane and ethylene from plastic in the environment. PLoS One, 13(8), e0200574.

Scharmer, O. (2018). The essentials of theory U: Core principles and applications. Oakland, CA: Berrett-Koehler Publishers.

Scharmer, C. O., \& Kaufer, K. (2013). Leading from the emerging future: From ego-system to eco-system economies. Berrett-Koehler Publishers.

Scharmer, C. O., \& Senge, P. M. (2009). Theory U: Leading from the future as it emerges. San Francisco, CA: Berrett-Koehler Publishers, Inc.

Schmidt, C., Krauth, T., \& Wagner, S. (2017). Export of plastic debris by rivers into the sea. Environmental science \& technology, 51(21), 12246-12253.

Senge, P. (Nov. 2014). Systems Thinking for a Better World [video]. Aalto Systems Forum. Aalto University. Retrieved from: https://www. youtube.com/watch?v=0QtQqZ605-0

Senge, P. (Oct. 2013). Systems Thinking and the Gap between aspirations and performance [video]. Garrison Institute. Retrieved from: 
https://www.garrisoninstitute.org/video/systems-thinking-and-the-gap-betweenaspirations-and-performance/

Senge, P. M. (2006). The fifth discipline: The art and practice of the learning organization. New York: Doubleday.

Smith, M., Love, D. C., Rochman, C. M., \& Neff, R. A. (2018). Microplastics in seafood and the implications for human health. Current environmental health reports, 5(3), 375-386.

Steffen, W., Crutzen, P. J., \& McNeill, J. R. (2007). The Anthropocene: are humans now overwhelming the great forces of nature. AMBIO: A Journal of the Human Environment, 36(8), 614-621.

Stroh, D. P. (2015). Systems Thinking for Social Change: A Practical Guide to Solving Complex Problems, Avoiding Unintended Consequences, and Achieving Lasting Results. White River Junction, Vermont: Chelsea Green Publishing.

Thompson, R. C., Moore, C. J., Vom Saal, F. S., and Swan, S. H. (2009). Plastics, the environment and human health: Current consensus and future trends. Philosophical Transactions of the Royal Society, 364, 2153-2166.

Tian, M., Chen, S., Wang, J., Zheng, X., Luo, X., and Mai, B. (2011). Brominated Flame Retardants in the Atmosphere of E-Waste and Rural Sites in Southern China: Seasonal Variation, Temperature Dependence, and Gas-Particle Partitioning. Environmental Science \& Technology, 45, 8819-8825.

Tue, N. M., Takahashi, S., Subramanian, A., Sakai, S., and Tanabe, S. (2013). Environmental contamination and human exposure to dioxin-related compounds in e-waste recycling sites of developing countries. Environmental Science Processes \& Impacts, 15, 1326-1331.

Tullo, A.H. (2019). Plastic has a problem; is chemical recycling the solution? C\&En, Vol. 97 (39). Retrieved on Sept. 16, 2020, from: https://cen.acs.org/environment/recycling/Plastic-problem-chemical-recyclingsolution/97/i39

Tyree, C., \& Morrison, D. (2017a). Invisibles: The plastic inside us. Orb Media. Retrieved on Sept. 17, 2020, from:

https://orbmedia.org/stories/Invisibles plastics/

Tyree, C., \& Morrison, D. (2017b). Plus Plastic: Microplastics Found in Global Bottled Water. Orb Media. Retreived on Sept. 17, 2020, from: https://orbmedia.org/stories/plus-plastic/

UN DES. (2018). Revision of the World Urbanization Prospects. Population Division of the United Nations Department of Economic and Social Affairs Publications. Retrieved on October 14, 2019, from: https://www.un.org/development/desa/publications/2018-revision-of-worldurbanization-prospects.html

UNEP. (2018). Single-Use Plastics: A Roadmap for Sustainability. Geneva: UNEP.

UNEP. (2014). Plastic Waste Causes Financial Damage of US\$13 Billion to Marine Ecosystems Each Year as Concern Grows over Microplastics. UNEP. 
Retrieved from: http://www. unep.org/newscentre/default.aspx?Document ID=2791\&ArticleID=10903

Vidal, J. (2014). Smelly, contaminated, full of disease: the world's open dumps are growing. The Guardian. Retrieved from: https://www.thequardian.com/global-development/2014/oct/06/smellycontaminated-disease-worlds-open-dumps

Viraj, R. K. L., Jayasiri, H. B., Devmali, N. L. D. H., Amarasiri, C., \& Jayapala, H. P. S. (2019). Plastic contamination in selected beaches of Sri Lanka with special reference to microplastics. NARA.

Wang, Jui-Liang (Director). (2017). Plastic China [documentary]. Retrieved from: https://www.plasticchina.org/

Weerakoon, W. R. W. M. A. P., Grøsvik, B. E., Dalpadado, P., Wimalasiri, H. B. U. G. M., Rathnasuriya, M. I. G., Harischandra, K. A. D. A. T., Shirantha, R.R.A.R., Madhushankha, H.M.T.C., Sampath, W.A.D., Jayasinghe, R.P.P.K., Gunasekara, S.S., Arulananthan, K., Totland, A., Indika, K.W., Mihirani, P.M.N., Priyadarshani, W.N.C., Arrigo, K.R., Bianchi, G., and Krakstad, J.o. (2019). Enumeration of microplastics in Sri Lankan waters: Preliminary findings from the RV Dr. Fridtjof Nansen Ecosystem Survey, 2018. NARA.

Wiek, A., Withycombe, L., \& Redman, C. L. (2011). Key competencies in sustainability: a reference framework for academic program development. Sustainability science, 6(2), 203-218.

Wilson, David C., and Costas A. Velis. (2015a). Waste management: -still a global challenge in the 21st century: An evidence-based call for action, Waste Management \& Research, 1049-1051.

Wilson, D. C., Rodic, L., Modak, P., Soos, R., Carpintero, A., Velis, C., Iyer, M., \& Simonett, O. (2015b). Global waste management outlook: Summary for decision-makers. ISWA \& UNEP: Vienna, Austria.

World Bank. (June 5, 2017). Oceans, Fisheries and Coastal Economies. Environment. Retrieved from: http://www.worldbank.org/en/topic/environment/brief/oceans

World Economic Forum, Ellen MacArthur Foundation, McKinsey \& Co. (2016). A New Plastics Economy: Rethinking the Future of Plastics. Retrieved on October 13, 2019, from: www.ellenmacarthurfoundation.org/publications

Yadav, V., Bhurjee, A. K., Karmakar, S., \& Dikshit, A. K. (2017). A facility location model for municipal solid waste management system under uncertain environment. Science of the Total Environment, 603, 760-771.

Yin, R. K. (2014). Case Study Research: Design and Methods, 5th Edition. Los Angeles: SAGE.

Zero Waste Academy. (2017). Zero Waste Kamikatsu. Kamikatsu, Japan: Zero Waste Academy. 1-9.

Zero Waste Cities. (2019). Best Practices. Zero Waste Cities. Retrieved on October 7, 2019, from: https://zerowastecities.eu/learn/\#best practice 
Zero Waste Europe. (2019). Our Network. Zero Waste Europe. Retrieved on october 7, 2019, from: https://zerowasteeurope.eu/our-network/

\section{Appendix}

Interview Questions

\begin{tabular}{|c|c|}
\hline $\begin{array}{l}\text { Interview } \\
\text { Guide }\end{array}$ & \\
\hline Introduction & $\begin{array}{l}\text {--Brief explanation of research } \\
\text { project \& IRB (researcher)-- }\end{array}$ \\
\hline $\begin{array}{l}\text { Warm Up: } \\
\text { (open } \\
\text { dialogue) }\end{array}$ & $\begin{array}{l}\text { - Name of } \\
\text { organization/position/livelihood, } \\
\text { geographical location, and people } \\
\text { involved (structural) } \\
\text { - } \text { Please briefly describe your } \\
\text { organization/position/livelihood and } \\
\text { your organization's role in materials } \\
\text { flows/waste management? (structural } \\
\text { attributes + agency) } \\
\text { Budget (agency) } \\
\text { organization/actor range of action } \\
\text { (rural or urban emphasis) (structural) }\end{array}$ \\
\hline \multicolumn{2}{|l|}{ Questions: } \\
\hline 1.) & $\begin{array}{l}\text { What is your biggest concern about materials } \\
\text { flows/waste in sri Lanka? (i.e. waste on } \\
\text { streets, pollution/environmental effects, } \\
\text { plastic buildup, education, lack of } \\
\text { political action, consumption increases and } \\
\text { resource depletion). (attitudinal/worldview } \\
+ \text { articulation of problem) }\end{array}$ \\
\hline
\end{tabular}




\begin{tabular}{|c|c|}
\hline 2.$)$ & $\begin{array}{l}\text { What are the biggest social challenges to } \\
\text { overcoming the above issue(s) and what } \\
\text { materials pose the biggest challenges (i.e. } \\
\text { specific plastics)? (attitudinal/worldview + } \\
\text { awareness + articulation of problem + path } \\
\text { dependency) }\end{array}$ \\
\hline 2.) & $\begin{array}{l}\text { [If not answered above] Are there specific } \\
\text { sites of concern (zones of sacrifice and } \\
\text { inequities causing systems imbalance)? Have } \\
\text { any sites been restored? } \\
\text { (attitudinal/worldview + upstream \& } \\
\text { downstream impacts } \\
\text { extraction/production/disposal + path } \\
\text { dependency) }\end{array}$ \\
\hline 3.) & $\begin{array}{l}\text { How do you see the (above) waste and } \\
\text { materials flows issues overlapping with } \\
\text { environmental issues? With social issues? } \\
\text { (attitudinal/worldview + upstream \& } \\
\text { downstream impacts) }\end{array}$ \\
\hline 4.$)$ & $\begin{array}{l}\text { How do consumption norms/levels play into } \\
\text { the above, and what are some of the most } \\
\text { noticeable shifts in consumption in recent } \\
\text { years (i.e. a shift from traditional bags to } \\
\text { plastic or visa-versa)? (attitudinal + } \\
\text { awareness of system + upstream } \\
\text { production/use) (Is it more socially } \\
\text { acceptable to continue the status quo for } \\
\text { sake of normalcy or seek for change? }\end{array}$ \\
\hline 5.$)$ & $\begin{array}{l}\text { How does waste effect your personal } \\
\text { relationship with the environment? }\end{array}$ \\
\hline
\end{tabular}




\begin{tabular}{|c|c|}
\hline & $\begin{array}{l}\text { (attitudinal }+ \text { awareness of the system }+ \\
\text { leverage point) }\end{array}$ \\
\hline 6.$)$ & $\begin{array}{l}\text { Who is responsible for changing the (above) } \\
\text { situation? (individual/ } \\
\text { community/city/nation/international/specific } \\
\text { agencies) (attitudinal/worldview + } \\
\text { responsibility) }\end{array}$ \\
\hline 7.$)$ & $\begin{array}{l}\text { Do you feel you have access to decision- } \\
\text { makers and others working on this issue? } \\
\text { (structural +access (blockages?)) }\end{array}$ \\
\hline 8.) & $\begin{array}{l}\text { What are your agency/organization's priority } \\
\text { areas for materials flows? (articulation of } \\
\text { problem/specific material) and what is your } \\
\text { main strategy for action (TOC and } \\
\text { methodologies for achieving (i.e. policy, } \\
\text { community organizing, LCA, zero waste, new } \\
\text { technology)? (transactional + knowledge } \\
\text { within system + path dependency on } \\
\text { experts/technical solutions or emerging } \\
\text { alternatives) }\end{array}$ \\
\hline 9.$)$ & $\begin{array}{l}\text { Are waste/materials flows your main focus } \\
\text { area or do you work simultaneously on other } \\
\text { issues? (i.e. waste and health) And/or do } \\
\text { you see your work overlapping with other } \\
\text { social and ecological/environmental issues? } \\
\text { (structural + attitudinal +transactional } \\
\text { +systems overlap + systems } \\
\text { awareness/blockages) }\end{array}$ \\
\hline 10.$)$ & $\begin{array}{l}\text { What organizations/agencies do you currently } \\
\text { work with? (provide example list) }\end{array}$ \\
\hline
\end{tabular}




\begin{tabular}{|c|c|}
\hline & $\begin{array}{l}\text { Are you open to more collaboration/could } \\
\text { there be more? (structural + transactional + } \\
\text { systems awareness/blockages) }\end{array}$ \\
\hline 11.$)$ & $\begin{array}{l}\text { Do you see any emerging trends or } \\
\text { alternative programs of action? (i.e. zero } \\
\text { waste) How does this inspire you? (attitudes } \\
+ \text { emerging strategies + systems } \\
\text { consciousness + leverage for change) }\end{array}$ \\
\hline 12.$)$ & $\begin{array}{l}\text { What are some of your biggest successes in } \\
\text { materials and waste management or others you } \\
\text { are aware of? (transactional + solutions } \\
\text { sets + leverage points for systems change) }\end{array}$ \\
\hline 13.$)$ & $\begin{array}{l}\text { What are you not seeing happen that you wish } \\
\text { would become a common practice/awareness? } \\
\text { (attitude/worldview +leverage for change) }\end{array}$ \\
\hline (14.) & $\begin{array}{l}\text { Where/who do you go to for continued } \\
\text { education on the impacts of waste and } \\
\text { material flows? (transactional + learning } \\
\text { system) }\end{array}$ \\
\hline (15.) & $\begin{array}{l}\text { Who else do you recommend me speaking to on } \\
\text { these topics? Are there certain sites I } \\
\text { should visit to better understand the } \\
\text { material flows/waste issues in colombo? } \\
\text { (structural) Is there anything else I } \\
\text { should have asked? (overall systems } \\
\text { awareness) }\end{array}$ \\
\hline Closing: & $\begin{array}{l}\text { Thank you very much for your time and } \\
\text { insights on these matters. I will be in } \\
\text { contact as the research progresses. Would } \\
\text { you like to take part in a forum on the }\end{array}$ \\
\hline
\end{tabular}


1

2

3

4

5

6

7

8

9

10

11

12

13

14

15

16

17

18

19

20

21

22

23

24

25

26

27

28

29

30

31

32

33

34

35

36

37

38

39

40

41

42

43

44

45

46

47

48

49

50

51

52

53

54

55

56

57

58

59

60 findings once I have finished compiling this research? 